(11) Nordic Council of Ministers

\title{
Ecosystem Restoration \\ for Mitigation of \\ Natural Disasters
}

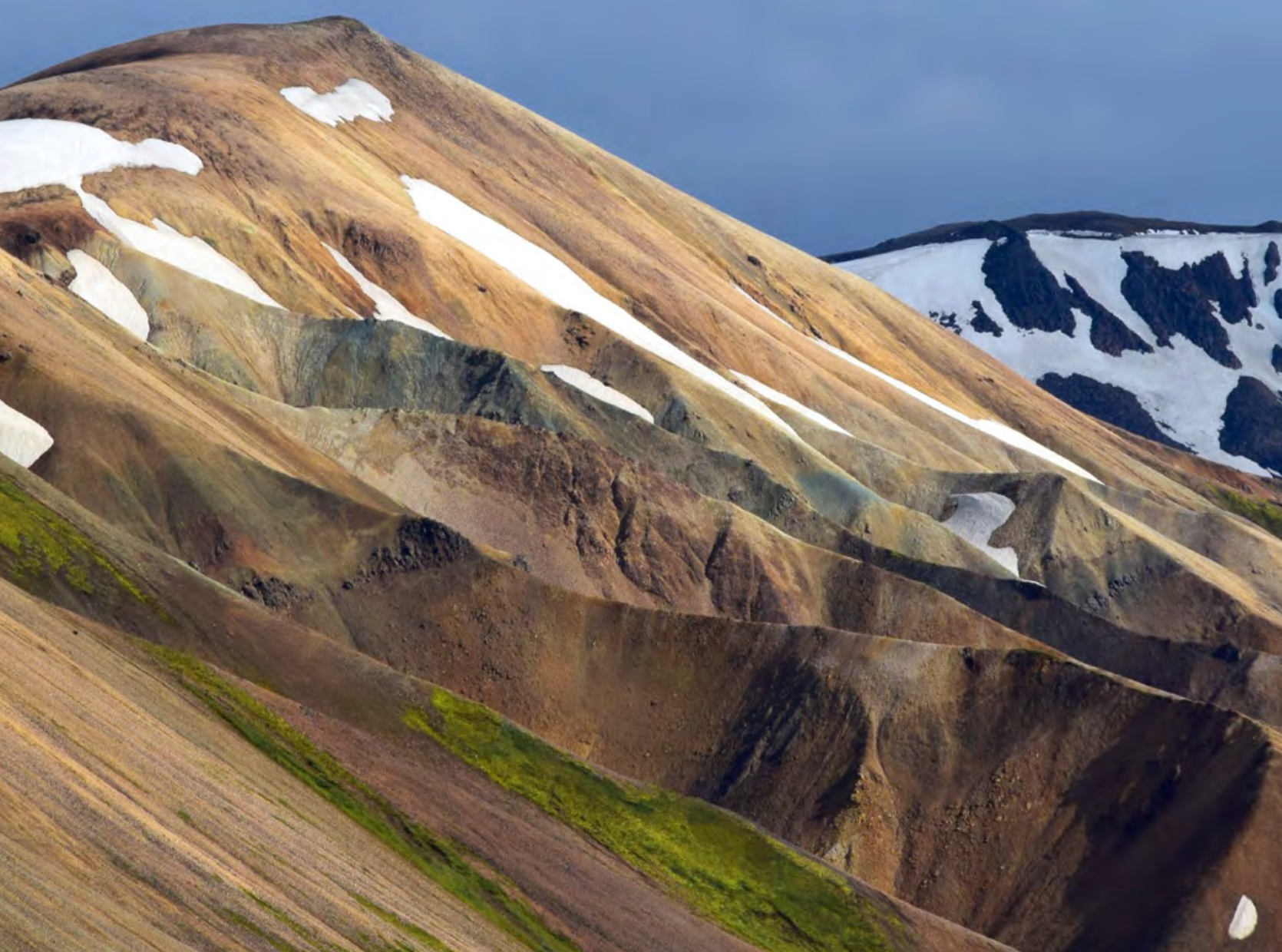





\section{Ecosystem Restoration for Mitigation of Natural Disasters}

Guđmundur Halldórsson, Anna María Ágústsdóttir, Ása L. Aradóttir, Ólafur Arnalds, Dagmar Hagen, Lis Mortensen, Christer Nilsson, Hreinn Óskarsson, Emmanuel Pagneux, Karoliina Pilli-Sihvola, Karsten Raulund-Rasmussen, Kristín Svavarsdóttir and Anne Tolvanen

TemaNord 2017:546 


\section{Ecosystem Restoration for Mitigation of Natural Disasters}

Guđmundur Halldórsson, Anna María Ágústsdóttir, Ása L. Aradóttir, Ólafur Arnalds, Dagmar Hagen, Lis Mortensen, Christer Nilsson, Hreinn Óskarsson, Emmanuel Pagneux, Karoliina Pilli-Sihvola, Karsten Raulund-Rasmussen, Kristín Svavarsdóttir and Anne Tolvanen

ISBN 978-92-893-5083-9 (PRINT)

ISBN 978-92-893-5084-6 (PDF)

ISBN 978-92-893-5085-3 (EPUB)

http://dx.doi.org/10.6027/TN2017-546

TemaNord 2017:546

ISSN 0908-6692

Standard: PDF/UA-1

ISO 14289-1

(c) Nordic Council of Ministers 2017

Cover photo: Scanpix

Print: Rosendahls

Printed in Denmark

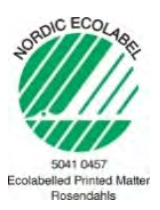

Although the Nordic Council of Ministers funded this publication, the contents do not necessarily reflect its views, policies or recommendations.

\section{Nordic co-operation}

Nordic co-operation is one of the world's most extensive forms of regional collaboration, involving Denmark, Finland, Iceland, Norway, Sweden, the Faroe Islands, Greenland, and Åland.

Nordic co-operation has firm traditions in politics, the economy, and culture. It plays an important role in European and international collaboration, and aims at creating a strong Nordic community in a strong Europe.

Nordic co-operation seeks to safeguard Nordic and regional interests and principles in the global community. Shared Nordic values help the region solidify its position as one of the world's most innovative and competitive. 


\section{Contents}

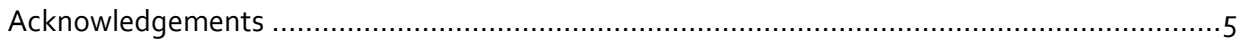

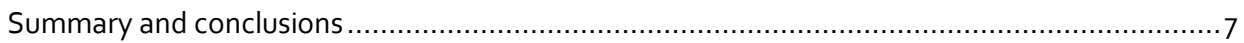

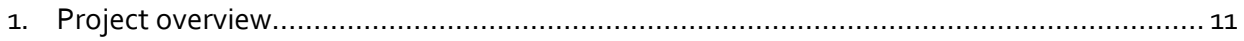

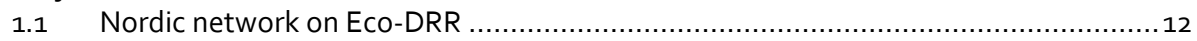

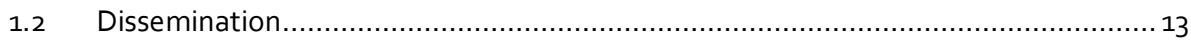

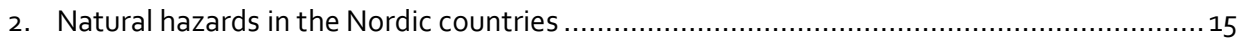

3. Ecosystem condition and ecosystem resilience in the Nordic countries .............................21

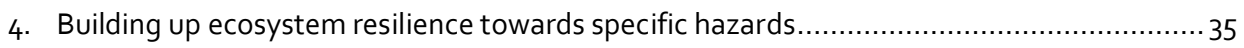

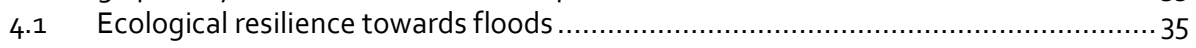

4.2 Ecological resilience of forests towards wind-throw ……....................................... 37

4.3 Ecological resilience towards deposition and secondary transport of volcanic tephra ...40

5. Integrating Eco-DRR and restoration of degraded ecosystems............................................ 43

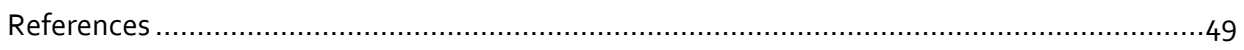

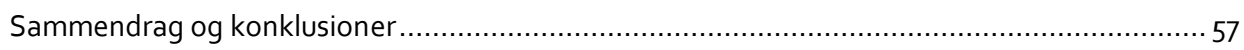

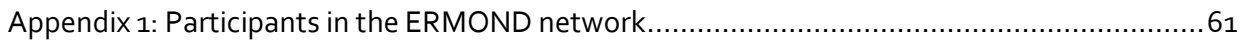

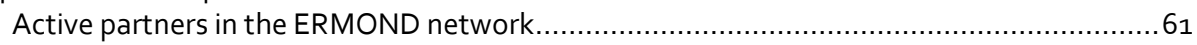

Partners associated to the ERMOND network ………................................................63

Appendix 2: Publications from, or in conjunction with, the ERMOND network.......................65

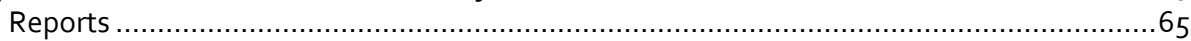

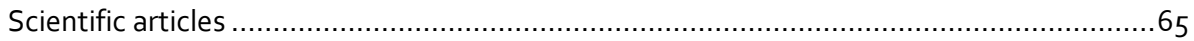

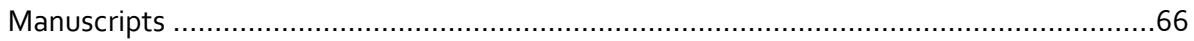

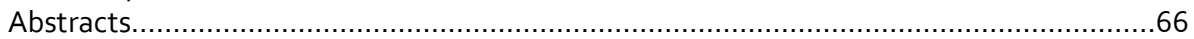





\section{Acknowledgements}

The ERMOND project was launched in 2014 as a subproject of NordBio, the theme project of the Nordic Council of Ministers, appointed by the Icelandic Ministry for the Environment and Natural Resources. The project was financed through the following funding schemes of the Nordic Council of Ministers: NordBio - The Program for Icelandic Presidency in NCM in 2014, The Terrestrial Ecosystem Group (TEG) and The Committee of Senior Officials for the Environment which funded the project NordEcRes, which was linked to the ERMOND project. Co-funding was supplied by the individual participating institutions and the Icelandic Avalanche and Landslide Fund.

The ERMOND group wishes to express gratitude to these funding agencies as well as others who have contributed to the ERMOND project. This includes the personnel of the participating institutions, as well as other institutions and individuals that contributed to the network through participation in workshops and other project activities. 



\section{Summary and conclusions}

This report contains the results of the Nordic network: ERMOND: ecosystem resilience for mitigation of natural disasters, which was launched in 2014 as a subproject of NordBio, the theme project of the Nordic Council of Ministers, appointed by the Icelandic Ministry for the Environment and Natural Resources.

The ERMOND network has reviewed information on natural hazards and ecosystem conditions in the Nordic countries and analysed the potential of mitigating the impacts of natural hazards in the region through the strategic build-up of ecological resilience. Furthermore, the ERMOND network has analysed how to integrate build-up of ecological resilience with national policies on restoration of damaged ecosystems. The following subjects were identified as keys for enhancing ecosystem-based approaches to disaster risk reduction (Eco-DRR) in the Nordic countries:

- Nordic disaster risk reduction (DRR) policies and strategies need to recognise that implementation of Eco-DRR solutions will become increasingly important in the future as continuously growing populations and predicted climate change are likely to increase the impacts of natural hazards in the Nordic societies.

- Ecosystem restoration for Eco-DRR must be integrated within existing policies and programmes for environmental protection, rural development and long-term sustainability targets.

- Ecosystem restoration for Eco-DRR should be linked to ecological restoration for protection and enhancement of biodiversity in a way that secures a win-win situation.

- Restoration of individual ecosystem services could conflict with other ecosystem services; this should be avoided by using integrated aims and approaches for restoration instead.

- Eco-DRR should be explored as first choice options and encouraged in order to reduce society's vulnerability to natural hazards. 
- Nordic DRR policies needs to recognise that Eco-DRR approaches also provide a wide array of other benefits for ecosystems, local economies, the social fabric and the broader environment.

- Nordic DRR policies needs to recognise that application of preventive measures and green solutions may provide less expensive alternatives compared to using only less sustainable engineering solutions or the high cost of post-event reactions. Benefits of improved ecosystem services and other indirect benefits should be considered when comparing options for DRR in cost-benefit analysis.

- Long term strategies for reducing future losses and aiding recovery from natural hazards need to be included as a part of sustainable land use and spatial planning.

- Information gaps need to be overcome to support decision making in Eco-DRR governance, exploring possible solutions, their cost-effectiveness and ecological benefits.

- Different sectors, including government, regional and local communities, scientific and engineering guidance and practice, and stakeholders need to be involved in promoting the use of ecological solutions to provide acceptable winwin solutions.

- Nordic cooperation on Eco-DRR policy has the potential to strengthen the Nordic influence in disaster risk reduction and environmental policy in the EU and other international contexts.

The reduction in the inherent ability of Nordic ecosystems to mitigate the impacts of natural hazards can have considerable consequences for Nordic societies. The result is that hazards, which might have been harmless given that the ecological resilience of ecosystems was intact, may turn out to be a serious disaster. This needs to be addressed.

The Nordic Council of Ministers (NCM) can play a central role in setting preventive actions for disaster risk reduction, such as ecosystem restoration, on the political agenda and can use the momentum to follow up on promising project results by financially supporting additional projects and investigations. The NCM/Terrestrial Ecosystem Group (TEG) could also play a central role in supporting Nordic cooperation within the field of ecosystem restoration and disaster risk management. National governments should also establish and implement targets for improved preventive action and post-event actions regarding ecosystem approaches for disaster risk reduction. They should also be 
responsible for implementing suitable policy measures to reach such targets and to ensure a balanced approach to restoration such as Eco-DRR to be integrated within existing policies and programmes for environmental and biodiversity protection, rural development and long-term sustainability targets. Local authorities such as municipalities need to implement local policy measures, planning of actions, and provide appropriate land use policy frameworks to fit the different needs of society regarding ecological restoration tailored to fit each local risk profile of natural hazards.

It is the conclusion of the ERMOND network that Nordic strategy on enhancing Eco-DRR solutions could make a critical contribution to the safety of Nordic societies and reduce losses of lives and economic damage. Such Nordic strategy would serve international benchmarking on DRR and facilitate international cooperation. 



\section{Project overview}

Various types of natural hazards occur in the Nordic countries. These hazards have primarily been tackled by early warnings before a disaster strikes, emergency relief during and after a disaster occurs, and disaster risk reduction measures to reduce the likelihood of a future disaster. A strategic build-up of ecosystem resilience could, however, serve well as a measure to reduce disaster risk in the Nordic countries. The aim of the ERMOND project was to facilitate new thinking and new solutions in preventing damage and loss of lives due to natural hazards in the Nordic countries, primarily by moving the focus from disaster management toward ecosystem-based preventive actions. These aims were approached through the following tasks:

- TASK-I: Establish and run a Nordic network of institutions dealing with: (a) protection against natural disasters and (b) ecological restoration.

The ERMOND network was consolidated at a kick-off meeting held in Iceland during May 22-23, 2014. Since then the network has held annual meetings to plan project activities and secure a flow of information. In total, fifteen institutions have participated in the ERMOND network, and another four were part of a wider network receiving information on project activities. Project partners came from all the Nordic countries. The network partners represented: (a) public organisations working with ecological restoration, (b) public organisations working with natural hazards, (c) public organisations working with protection of the environment, and (c) the scientific community. A list of participating institutions and network participants is given in Appendix 1:

- TASK-II: Demonstrate, through a report \& a policy paper, how build-up of ecosystem resilience can be: (TASK-II-a) used for mitigation of natural disasters in the Nordic countries and (TASK-II-b) integrated with Nordic policies on restoration of degraded ecosystems. 
Work on TASK-II-a was initiated during the project kick-off meeting and further developed at the workshop: Use of ecological restoration for mitigation of natural disasters in the Nordic countries, held in Gunnarsholt, Iceland, May 18-22, 2014. The results from this subtask are summarized in this report, a policy paper and a review article on how build-up of ecosystem resilience can be used for mitigation of the impacts of natural hazards in the Nordic countries (Agustsdottir et al. in manuscript). Furthermore, a database on the impacts of natural hazards in the Nordic region and the potential of ecosystems to mitigate natural disasters was structured under this subtask.

Work on TASK-II-b was initiated at the workshop: The risk of ignoring biodiversity when restoring for ecosystem services, held in Oslo, Norway on December the 3rd, 2015. The results from this subtask are summarized in this report, a policy paper and a peerreviewed article (Hagen et al. in prep.):

- TASK-III: Case studies on enhancing resilience towards natural hazards through ecological restoration and improved land use management.

The following three case studies were conducted: (a) Ecological resilience towards floods, (b) Ecological resilience towards volcanic ash, and (c) Ecological resilience of forests towards storms. These case studies were primarily conducted as desk studies, supported with workshops. The results from these subtasks are summarized in the present report, policy paper and several peer-reviewed articles:

- TASK-IV: Dissemination. The results from the project are disseminated through reports, scientific articles, scientific conferences, and the webpages: http://ermond.land.is and http://nordbio.org/. Other media were also used to disseminate results from the network including interviews in newspapers and on radio and presentations at various other forums.

\section{$1.1 \quad$ Nordic network on Eco-DRR}

The creation of a Nordic network on ecosystem-based approaches to disaster risk reduction (Eco-DRR) was considered an important step for enhancing Eco-DRR in the Nordic countries as no such forum has previously existed. This has enhanced the flow of information about valuable experiences and findings between and within countries. 
Information gathered by the ERMOND network showed that different countries have different natural hazard profiles and that the potential of ecosystems to mitigate the impacts of natural hazards differs among the Nordic countries (Agustsdottir et al. in manuscript). Facilitation of information exchange on Eco-DRR among the Nordic region may be expected to facilitate new solutions for disaster risk reduction in the region and strengthen the Nordic influence in disaster risk reduction and environmental policy in the EU and other international contexts.

\subsection{Dissemination}

Dissemination from the project will include the present report, a policy brief, a chapter in the final report from the NordBio program and a scientific article summing up the major results from the project. The ERMOND website provides further information, see http://ermond.land.is/. In addition to this, the ERMOND network will publish scientific articles presenting results from project case studies and a scientific article on how to integrate restoration of ecosystem resilience with Nordic policy on restoration of disturbed ecosystems. A list of these publications is in Appendix 2. Furthermore, the ERMOND project and project results have been presented at the following conferences:

- Nordtic - Nordic Bioeconomy and Arctic Bioeconomy. Conference on Nordic Bioeconomy and Arctic Bioeconomy held on June 25th, 2014, in Selfoss, Iceland. Title of presentation: Assessing and mitigating risk in the Nordic Bioeconomy by Guðmundur Halldórsson, ERMOND project leader. http://www.matis.is/nordtic/nr/3974

- NordRegio conference, Nordic Bioeconomy and Regional Innovation Nov. 12-13, 2014 in Keflavik, Iceland. Title of presentation: Introduction to NordBio examples: Wood biomass - Ecosystem resilience - Biofuels for the fishing industry by Danfriður Skarphéðinsdóttir, Head of Division, Ministry for the Environment and Natural Resources, Department of Oceans, Water and Climate. http://www.nordregio.se/Global/Events/Events\%202014/Nordregio\%20Forum\%2 02014/Nordregio\%20Forum\%202014\%2oprogramme_14.pdfSER

- SER Europe conference 2016: Best Practice in Restoration, 22-26 August in Freising, Germany. A specific workshop: Ecological restoration for disaster risk 
reduction was held by the project group during the conference. The workshop was opened by a short introduction of the ERMOND project. The workshop dealt with the questions: how do we restore ecological resilience towards natural hazards; and how do we balance different goals within ecological restoration. Several oral and poster presentation from the ERMOND project were submitted at the conference. http://ermond.land.is/news-and-events/ser2016/

- NordBio final conference. Minding the future. Bioeconomy in a changing Nordic reality: 5-6 October in Reykjavík, Iceland. During the conference, the ERMOND network, in cooperation with the NORDRESS project, conducted the workshop: Minding Future Disasters. The workshop consisted of discussions between a media reporter, panel of experts and the audience on the questions: Which changes in natural disasters can we expect in the future; how will they challenge Nordic societies and; how can they be met? http://ermond.land.is/news-andevents/nordbio-final-meeting-minding-the-future/ 


\section{Natural hazards in the Nordic countries}

Natural hazards are a major threat to all human societies and cause serious damage every year. During 2000-2009, average annual casualties world-wide from natural hazards came to 80,000 people and over 200 million people were affected (CRED CRUNCH 2011). Direct annual economic losses from disasters due to natural hazards are over USD 100 billion, not including uninsured losses (UNISDR 2013). The number of disasters reported worldwide has increased rapidly since the 1960 s and is expected to increase further following predicted future climate change (Renaud et al. 2013; UNISDR 2013).

Hazard is defined by the United Nations Sendai Framework for Disaster Risk Reduction (United Nations 2015) as "A potentially damaging physical event, phenomenon or human activity that may cause the loss of life or injury, property damage, social and economic disruption or environmental degradation. Hazards can include latent conditions that may represent future threats and can have different origins: natural (geological, hydro-meteorological and biological) or induced by human processes (environmental degradation and technological hazards)". Geo-hazards include earthquakes; volcanic eruptions, submarine landslides, tsunamis, incipient coastal erosion, and hydro-meteorological hazards consist of floods, storm surges, sea ice, avalanches, droughts, storms, thunderstorms and heat waves. In some cases, our modern societies are more vulnerable to natural hazards than societies in the past, especially due to urbanization and economic globalization (Huppert and Sparks 2006; Gencer 2013; Ágústsdottir 2015). Research on climate change and its impact predicts an increase in frequency and/or intensity of various hydro-meteorological extreme events (IPCC 2007; IPCC 2012).

Many natural hazards threaten the Nordic countries. Natural hazards in the Nordic countries, except Iceland, were summarized in a report produced within the framework of the ESPON 2000-2006 programme (Schmidt-Thome 2006) and an overview of geohazards in the region was published by Nadim et al. (2008). The major hazards for the whole region are floods, landslides, storms and cyclones, and snow avalanches (Nadim 
et al. 2008). The information given in the ESPON report is presently the most detailed overview of natural hazards in the Nordic countries, excluding Iceland. Overviews of specific hazards in individual countries have partly been published, such as Sólnes et al. (2013) which gives an overview of volcanic activities and earthquakes in Iceland.

These hazards vary among the countries due to geographical and geological differences (Schmidt-Thome 2006). Iceland is the only country where volcanic and seismic hazards are of significance (Nadim et al. 2008). The coastal areas are primarily threatened by storm surges/winter storms and floods; the alpine-areas are threatened by avalanches/landslides and floods; river valleys are threatened by river floods; and areas that are located above tectonic active zones are threatened by volcanic eruptions and earthquakes, tsunamis and landslides.

Figure 1: The volcane Eyjafjallajökull, in South Iceland, in eruption in 2010. The farm Porvaldseyri is in the forground

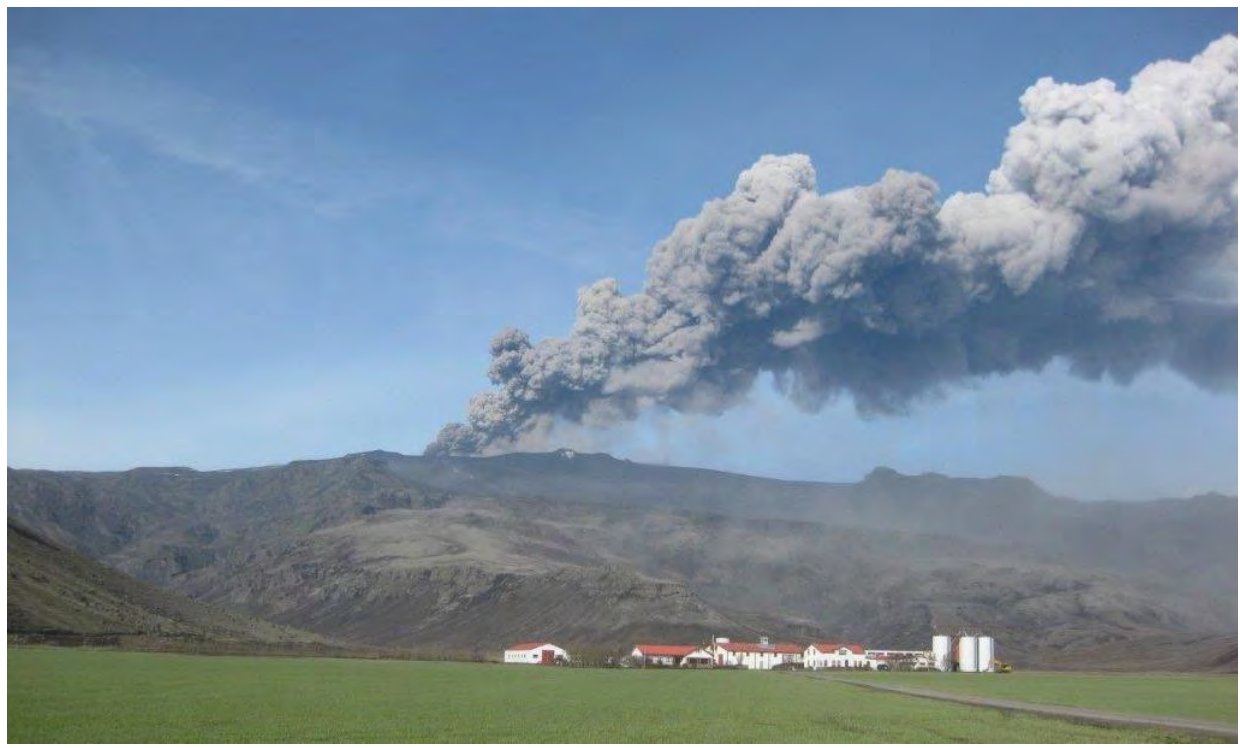

Photo: Sveinn Runólfsson. 
The ERMOND network summarised the impacts of natural hazards in the Nordic countries (Agustsdottir et al. in manuscript). Most fatalities are caused by avalanches and landslides, primarily in Norway and Iceland. During the period 1901-2015 over 1000 lives were lost in Norway due to avalanches and landslides and over 200 in Iceland (Agustsdottir et al. in manuscript). Sea floods and storms are also the cause of many fatalities. During the period 1901-2015 floods from the sea and storms each caused 7080 fatalities in total in the Nordic countries (Agustsdottir et al. in manuscript). Most economic damage is caused by storms, but droughts, avalanches and landslides, and floods also cause considerable economic damage. During the period 1990-2015 economic damage caused by storms came to over USD 4 billion in Denmark and over USD 0.6 billion in Finland (Agustsdottir et al. in manuscript). Data on the economic impacts of these hazards are largely available through re-insurance companies; however, such data can have limitations based upon what is insured and what is not. Furthermore, the insurance cover and the legal basis for such insurance in the Nordic countries differs (Garne et al. 2013). Publicly available disaster impact databases also exist, for example the EM-DAT international disaster database. Indirect impacts are often difficult to determine and their impact characterization is problematic (Harjanne et al. 2016). Data collected by insurance companies do not include health effects, secondary effects or transfer of impact is often not recorded, and often there is limited or no knowledge gathered on the production loss due to disasters. Similarly, the impact of changes or deferrals made due to hazards is not recorded. For example, if trucking of goods is abandoned it may be recorded and accounted for, but if trucking of goods is changed to another lengthier route to avoid hazard impact at much extra cost, the impact may not be recorded or accounted for. Such an example exists from Iceland during the Eyjafjallajökull eruption where transport of cargo was changed to the northerly route instead of the traditional shorter southern route around Iceland. Accounting of costs such as risk mitigation cost (restoration cost) often only contain official numbers for official rehabilitation costs from government/municipality that are available but do not take into account the cost paid or endured by individuals. 
Figure 2: Flood in Skaftá River, in South Iceland, in 2015

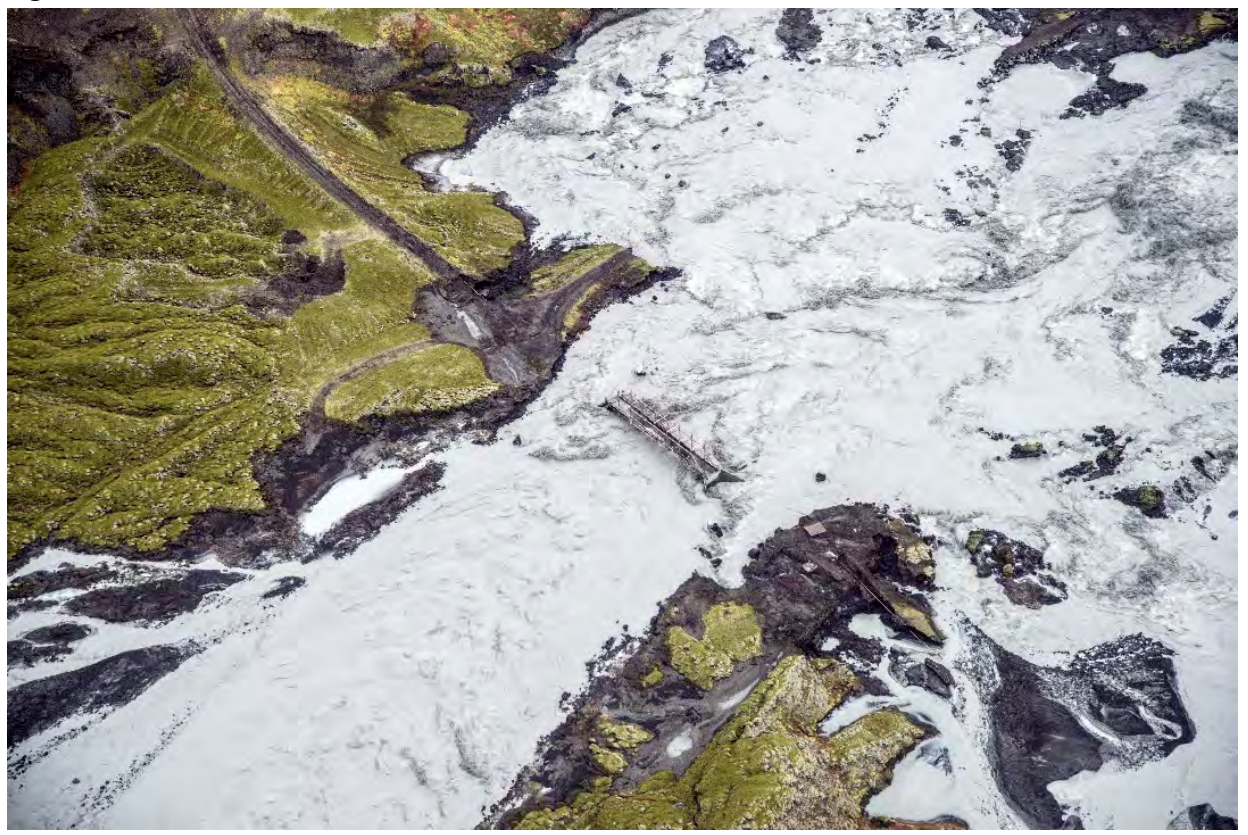

Photo: Sigurjón Einarsson.

Several databases on natural hazards and their impacts exist in the Nordic countries. The Norwegian University of Science and Technology has produced natural hazard vulnerability maps for municipalities in Norway (NORKLIMA 2016). Each municipality in Denmark is responsible for creating $100 \times 100 \mathrm{~m}$ flood risk maps as part of the national flood risk screening effort (Danish Nature Agency 2016). In Iceland, information on natural hazards is gathered by the Icelandic Meteorological Office and can be accessed through their webpage (vedur.is). This includes, for example, information on earthquakes and volcanic eruptions (http://en.vedur.is/earthquakes-andvolcanism/volcanic-eruptions/ and http://icelandicvolcanoes.is/) and avalanches (http://en.vedur.is/avalanches/imo/). For the Nordic countries (except for Iceland) the European "Mapping and Assessment of Ecosystems and their Services" (MAES) classification can provide ecological data (http://biodiversity.europa.eu/maes/maesdigital-atlas). In Finland, the Finnish Environment Institute has published flood risk maps. The Finnish meteorological Institute (FMI) has published Finnish all-weather data 
as open data due to the initiative of the Finnish government and the INSPIRE directive of the European Union. Currently, FMI is developing a database on weather impacts with the purpose of using it for weather and climate risk analysis and development of impact-based weather forecasts. Flood risk maps:

- In Finnish: http://paikkatieto.ymparisto.fi/tulvakartat/Html5Viewer_2_7/?locale=fi-FI

- In English: http://www.environment.fi/floodmaps

- FMI open data: http://en.ilmatieteenlaitos.fi/open-data-manual

In Iceland, the Agricultural University of Iceland has created a database on erosion status, vegetation and land use (Nytjaland 2017). In Finland, the National Forest Inventory (NFI) produces a wealth of data on different aspects of forest resources, forest health and biodiversity, land use and forest ownership and forest carbon stock and changes. The inventory has been conducted since the 1920 s on a five to ten year interval. Data are provided as statistics and maps (http://www.metla.fi/ohjelma/vmi/vmi-moni-en.htm).

In the ERMOND network a database was structured, with the aim of including data on the occurrence and impacts of natural hazards in the Nordic region and on the regional use of Eco-DRR in the mitigation of these hazards. This database is based on the need to provide a tool to handle data; 1 ) occurrence of natural hazards; 2 ) their impacts; 3) status of ecosystems; and 4 ) how ecological restoration is used in the Nordic countries for Eco-DRR. The ERMOND database is intended to provide support for collecting information on the aforementioned parameters in a normalized and homogeneous way to form a basis for future work on disaster risk reduction in the Nordic countries. Therefore, the database is an important deliverable from the ERMOND project as a tool by which meaningful information can be brought to the attention of the authorities. 



\section{Ecosystem condition and ecosystem resilience in the Nordic countries}

Extensive human induced ecosystem exploitation has resulted in a degradation of important ecosystem services, including the capacity of ecosystems to provide protection against natural hazards (Millennium Ecosystem Assessment 2005). Examples include reduced resilience towards flooding (Nilsson et al. in review), tephra deposition and sand storms (Arnalds 2013; Ágústsdóttir 2015), erosion (Imeson 2012), landslides (Sidle et al. 2006) and avalanches (Sakals et al. 2006). Global climate change is likely to escalate this development (Millennium Ecosystem Assessment 2005).

The vulnerability of societies to natural hazards is highly dependent on the state of the ecosystems (UNEP 2009). The Nordic countries have experienced large scale ecosystem degradation. The native birch woodlands of the Faroe Islands and Iceland, respectively, have been almost or totally removed (Eggertsson et al. 2008), peatlands in Finland and wetlands in Iceland have been drained (Similaa et al. 2014; Arnalds et al. 2016), many nemoral forests in Denmark have been lost and often replaced with plantations of introduced conifers (Fourth Country Report to CBD - Denmark 2010), and streams and rivers have been channelized and dammed (Nilsson et al. in review). In Sweden, almost no pristine forests are left and major parts, especially in southern Sweden, have been transformed into agricultural land. In addition, large areas have been subject to urbanisation or building of various infrastructures. In Norway areas of intact wilderness (areas without technical infrastructure) have decreased dramatically during the last decade, e.g. during 2008-2012 decreased by $900 \mathrm{~km}^{2}$ [http://inonkart.miljodirektoratet.no/inon/kart]).

The ERMOND network has summarised the status of Nordic ecosystems, primarily based upon information given in National reports to the Convention on Biological Diversity (https://www.cbd.int/reports), supported with other information as needed. 
We confined our summary to following major habitat types: Alpine habitats, forests, wetlands/peatlands, freshwater habitats and farmland.

ALPINE HABITATS: Alpine habitats cover large parts of the Nordic region. Almost $90 \%$ of the Faroe Islands are alpine areas (Olsen 2014). There are also extensive alpine areas in Norway, Iceland and Sweden.

Alpine areas in Norway cover almost 120,000 km2 (http://www.skogoglandskap.no/kart/kilden). Anthropogenic effects on biological diversity within this biome are relatively small given the sparseness of physical encroachments; however the increasing fragmentation due to infrastructure, hydropower plants, sports facilities and cabin building has negative effects on populations of migrating wildlife and ecosystem functions (Nilsen \& Strand 2017). In recent years the ecologically important small rodent cycle in the mountains has been absent or greatly reduced. This may be due to grazing pressure or climate change.

Figure 3: Degraded land in Skógaheiði, in the highlands of South Iceland

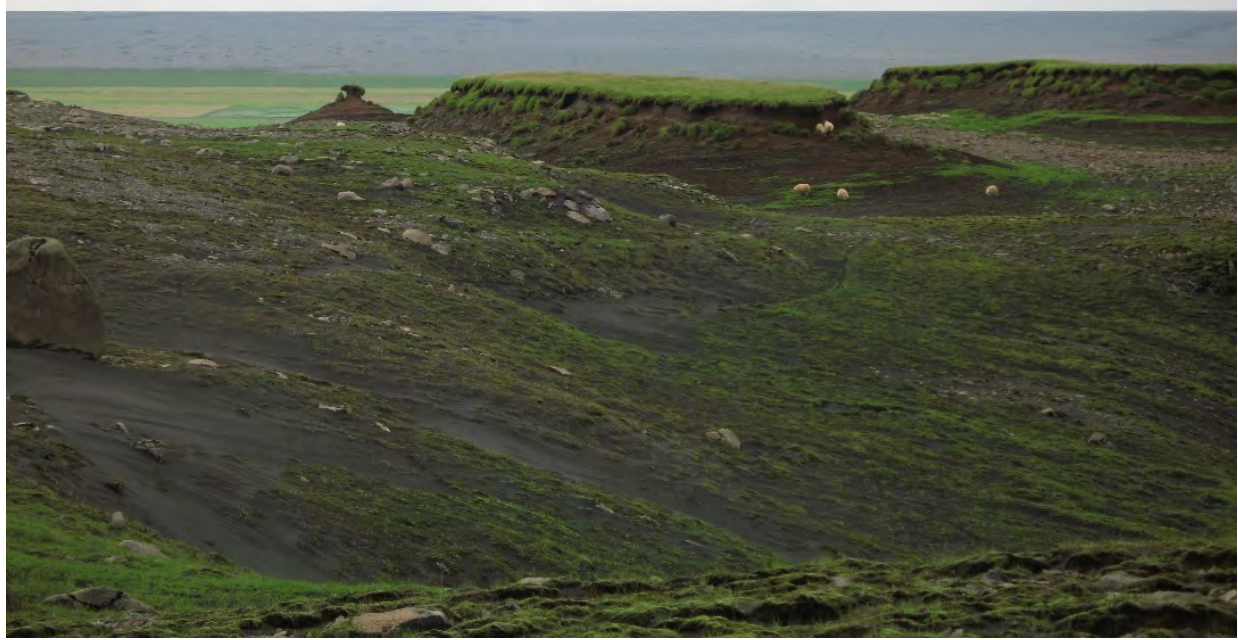

Photo: Ása L. Aradóttir. 
Alpine areas in Iceland, defined as land above 400 meters above sea level, cover almost $60,000 \mathrm{~km}^{2}$ (Arnalds 2015). Around $55 \%$ of the Icelandic alpine habitats are sparsely vegetated. These areas were formerly largely covered with heathland vegetation, which has been degraded in historic time due to grazing, combined with harsh environmental conditions and volcanic activity (Arnalds 2015; Ágústsdóttir 2015). There is growing pressure for development of the highlands, especially from the energy sector (construction of dams and hydro and geothermal plants) and tourism (Ministry for the Environment and the Icelandic Institute of Natural History 2001).

Alpine areas in Sweden cover almost 40,000 km² (Statistiska Centralbyrån 2017). This includes natural meadows and heathland, including shrub areas and unforested exposed bedrock and boulder areas. Disturbance has increased in alpine areas during the past 50 years, through the rapid development of tourism and the increased use of cross-country vehicles (Gunnarsson and Löfroth 2014).

Finland's alpine habitats comprise some $15,000 \mathrm{~km}^{2}$ of the country (Ahokumpu et al. 2014). These are either treeless mountain tops or semi- open mountain birch forests lying normally higher than 300 metres above sea level. The condition of lichen grounds has been deteriorating for over the past two decennia due to the high level of reindeer herd grazing. This has also other negative impacts on the alpine flora and fauna including the deterrence of regrowth of mountain birch forest after autumn moth outbreaks. Other pressures on alpine habitats include tourism and off-road traffic. The disturbances by tourism in alpine areas can include the trampling and resultant erosion of vegetative cover (Ahokumpu et al. 2014; review by Tolvanen and Kangas 2016).

In general, there is an increasing pressure on alpine habitats in Finland, Sweden and Norway. This is of concern as alpine ecosystems are often fragile and this can cause loss of resilience towards natural hazards: such as landslides, avalanches, erosion, and insect outbreaks. In Iceland most alpine habitats are seriously degraded. This affects the ability of these habitats to mitigate natural disasters, primarily volcanic tephra fall and sand encroachment. The ability to store and mitigate water is also largely lost, which increases the likelihood of floods in lowland areas. 
FORESTS: Forests cover large parts of Finland, Sweden and Norway. Denmark has considerable forest coverage, whereas Iceland and the Faroe Islands have very little forest coverage.

In Finland forests cover some $230,000 \mathrm{~km}^{2}$ (State of Finland's Forests 2012). Nearly all the Finnish forests are classified as semi-natural forests showing characteristics of human impact. Forest management in Finland's boreal zone typically involves managing even-aged stands. Therefore, the forest landscape is mostly mosaic-like due to differences between individual stands in age structure, the timings of regeneration and management procedures, and tree species composition. The amount of unmanaged forests is $4 \%$, of which nearly $60 \%$ are located in protected areas (State of Finland's Forests 2012). About $7 \%$ of forests are defined as natural or close to natural old-growth forests (Finnish Statistical Yearbook of Forestry 2014).

In Sweden forests cover about $220,000 \mathrm{~km}^{2}$, not including forests on peatlands (Statistiska Centralbyrån 2017). Swedish forests are primarily boreal forests, although nemoral forests are found in South Sweden (Forests and Forestry in Sweden 2017). The main threats to the Swedish forest are reduction of habitat connectivity and loss of specific habitat features due to intensification of forestry during parts of the 2oth century (Fifth National Report to the Convention on Biological Diversity - Sweden 2014). In general, the forest landscape in Sweden is dominated by commercially managed even aged forests, and old growth or untouched forests are rare (Forests and Forestry in Sweden 2017). In addition, many of the natural disturbance regimes such as fire and flooding have been controlled, which has put many of the processes of the natural ecosystems under pressure (Forests and Forestry in Sweden 2017). 
Figure 4: Managed pine forest, Lentua Natura 2000 site, eastern Finland. The forest is characterised by single age and single tree species structure. Notice the lack of decaying wood

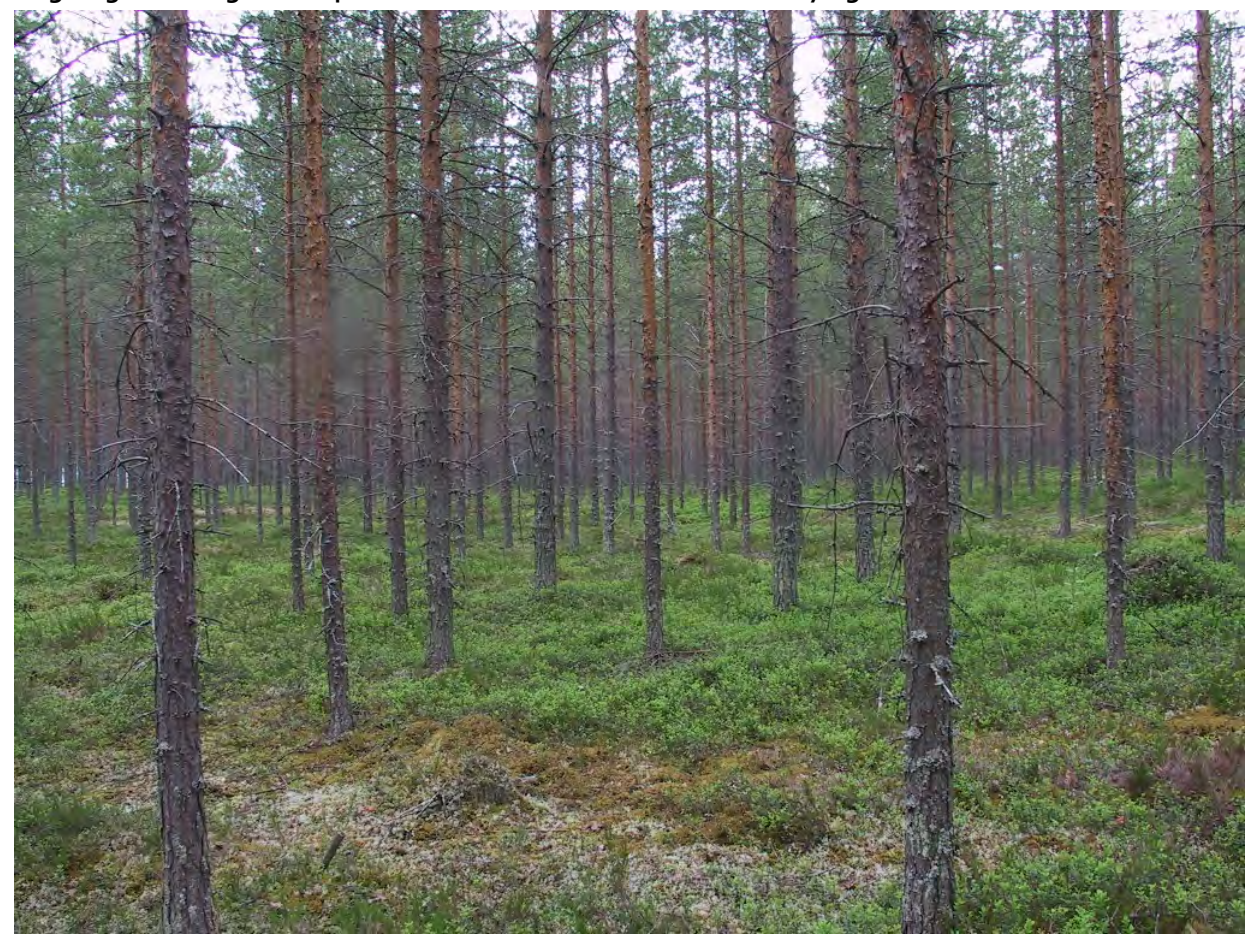

Photo: Anne Tolvanen.

Forests in Norway cover about 100,000 km² (Norway's Fourth National Report to the Convention on Biological Diversity 2009). A part of this area is commercially unviable mountain forest, wooded bog, or other woodland in low-productivity terrain, but the major part (60\%) is commercial forest. However, commercial forestry results in habitat changes that may lead to acute habitat loss, as well as fragmentation of forest habitats. Therefore, forest species and habitats are under pressure (Nature Index of Norway 2015), and most of the red-listed species in Norway are found in forests (Henriksen and Hilmo 2015). There has been an increase in biologically mature forest due to less logging of commercially matured forest, which amounts to $6 \%$ of the commercial forest area of Norway (Norway's Fourth National Report to the Convention on Biological Diversity 2009). 
Figure 5: Pristine pine forest, Oulanka national Park, northeastern Finland. Notice the decaying wood

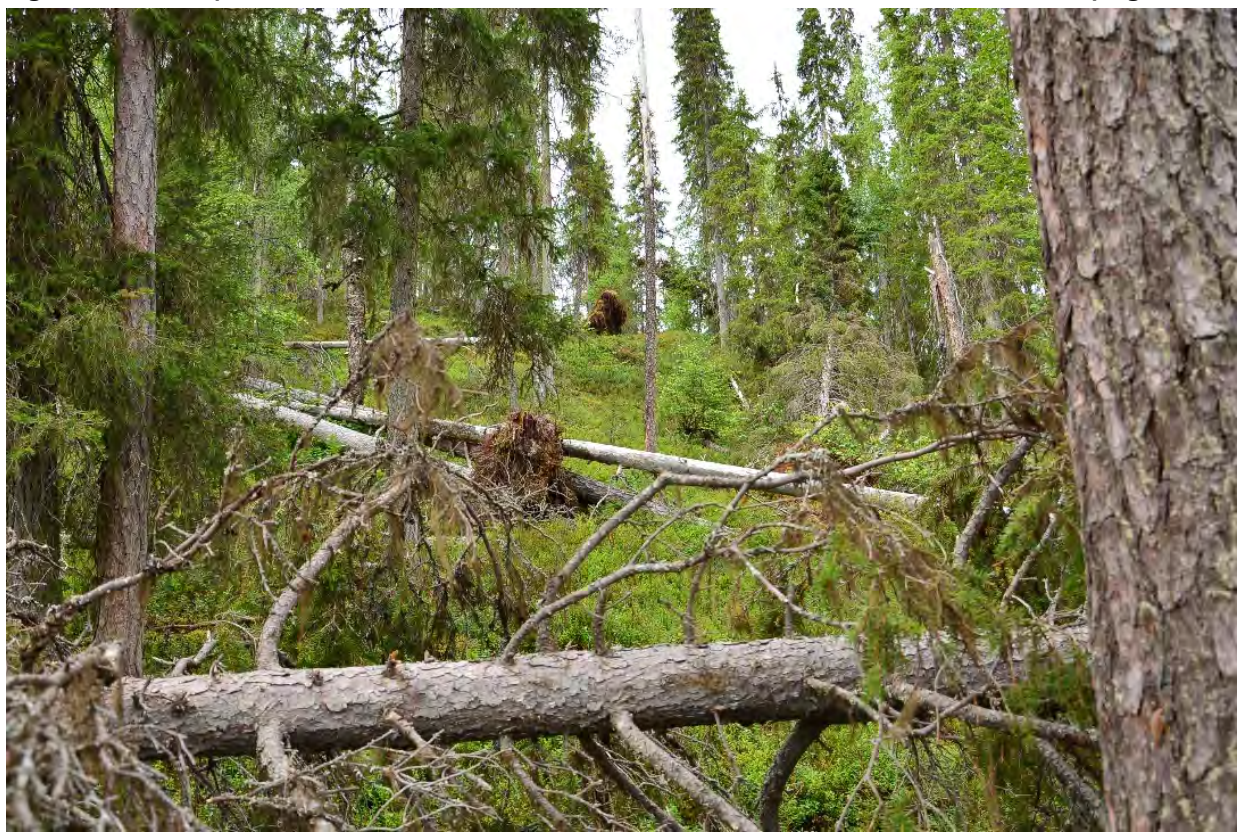

Photo: Anne Tolvanen.

Forests in Denmark cover almost $6,000 \mathrm{~km}^{2}$; conifers take up $50 \%$ of the total forest land, while deciduous trees account for $46.4 \%$. The remaining area is bare or a specific tree species has not been identified in the area (Ministry of Environment and Food of Denmark 2017). The forest area in Denmark has increased by almost 100\% from 1800 to 2000; however, recent investigation indicates a simultaneous decrease in the area of natural forest with old-growth qualities. In general, forest management has started to shift towards sustainable management, which is a challenge considering that many forests are very homogenous and look like plantations. An important objective of the National Forest Programme (2002) is to promote a conversion to "close to nature forestry" (Fourth Country Report to CBD - Denmark 2010).

In Iceland the total cover of forests and woodlands is about 1,900 $\mathrm{km}^{2}$, of which native birch woodlands cover over $1,500 \mathrm{~km}^{2}$ (Snorrason et al. 2016) and about $420 \mathrm{~km}^{2}$ cultivated forests with exotic tree species and native birch (Snorrason 2016). Iceland has lost over $95 \%$ of its original birch woodlands, which today cover only about $1.5 \%$ of the 
total area (Snorrason 2016). The primary threat to forests is grazing, mainly by sheep, which hinders rejuvenation of native woodlands. Introduction of new pest species and changes in pest dynamics due to climate change also pose a significant threat towards native as well as introduced tree species (Halldorsson et al. 2013).

In general, the commercially managed boreal forests of Sweden, Finland and Norway have been subject to various management activities which have affected their characteristics over the last few hundred years. This causes habitat changes as well as fragmentation of forest habitats, which has caused degradation of biodiversity and is likely to decrease the ecological resilience of the boreal forests towards natural hazards. Forests in Denmark are of different character, as considerable plantation of exotic conifers has been established, which is likely to make them more vulnerable to natural hazards than the boreal forest:

WETLANDS: This habitat is most extensive in Finland and Sweden.

In Finland peatlands cover around $85,000 \mathrm{~km}^{2}$ (Finnish Statistical Yearbook of Forestry 2014). Altogether over $60 \%$ of Finland's original peatland area has been drained for forestry, used for agriculture or peat extraction, been submerged under hydropower reservoirs, or developed with buildings and infrastructure. This has resulted in a complete or partial destruction of the original habitats. Furthermore, the connectedness of pristine peatlands has decreased markedly and the shapes of individual peatlands have changed to sharp-edged drainage delimited polygons (Ministry of the Environment 2010). However, recent actions in Finland to restore peatlands are likely to counteract this, at least in protected areas (Similä et al. 2014).

Swedish peatlands have been estimated to cover around $52,000 \mathrm{~km}^{2}$ (Statistiska Centralbyrån 2017). About $80 \%$ of these have been disturbed by human activities, especially by drainage. The proportion of untouched peatlands is highest in the sparsely populated areas close to the Alpine zone, and lowest in areas with a high population and a high proportion of agriculture (Gunnarsson and Löfroth 2014)

In Norway peatlands cover $17,000 \mathrm{~km}^{2}$ (Norway's Fourth National Report to the Convention on Biological Diversity 2009). Bog and marshland are relatively extensive biotopes in Norway. From 1950-1990 a comprehensive draining of wetland areas for forestry, agriculture, or building purposes took place. It is estimated that $25 \%$ of the original mire area below the tree line has been drained (Moen 1995).

Icelandic wetlands cover about $9,000 \mathrm{~km}^{2}$ (Arnalds et al. 2016). Presently, about $47 \%$ of these wetlands are impacted by drainage, due to extensive drainage since the middle of the zoth century. Originally this was done for agricultural purposes; however, 
only a fraction of the drained wetlands is used for agriculture (Arnalds et al. 2016). Attempts to restore Icelandic wetlands have resulted in few projects and only small areas of the original wetlands have been restored (Óskarsson 2011).

In Denmark wetlands cover around $800 \mathrm{~km}^{2}$; this includes freshwater wetlands and salt marshes (Stjernholm and Kjeldgaard 2005). Danish wetlands have been extensively drained. Old maps show that around 1900 the area of low-lying soils constituted around $7,500 \mathrm{~km}^{2}$ (Hoffmann and Baattrup-Pedersen 2006). Urban development has also caused significant changes to watercourse systems, and water and wetlands. Wetland restoration is prioritised in the Danish national environmental management programme. From 1990 to 2009 an area of wetlands amounting to $0.4 \%$ of the total land area of Denmark has been restored, primarily as lakes or meandering streams, but terrestrial wetlands have also been restored (Hoffmann and Baattrup-Pedersen 2006).

Figure 6: Drained wetland in West Iceland

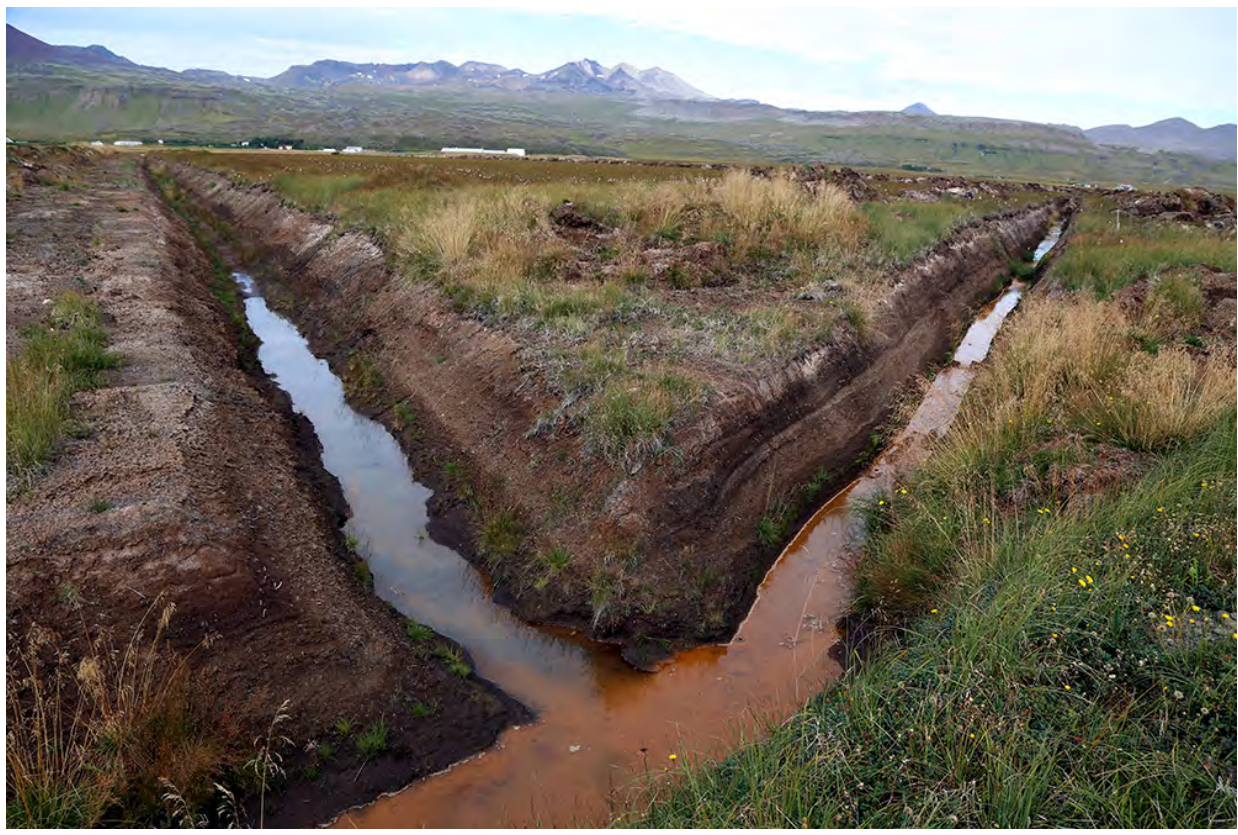

Photo: Hlynur Óskarsson. 
In general peatlands and wetlands in the Nordic countries have been seriously degraded and the greater part of these habitats has been lost. The extensive drainage and fragmentation of Nordic peatlands and wetlands has seriously reduced the ecological resilience of this important habitat and the potential of peatlands/wetlands to store and mitigate water has been significantly reduced. This increases the danger of floods and droughts and reduces the potential of peatlands/wetlands to limit the spread of forest or vegetation fires.

FRESHWATER HABITATS: Freshwater habitats include lakes, ponds, rivers and streams. This habitat is most extensive in Finland, Sweden and Norway.

In Sweden freshwater habitats cover almost 40,000 km² (Statistiska Centralbyrån 2017). More than 90,000 lakes cover almost $9 \%$ of the country, and there are more than $500,000 \mathrm{~km}$ of streams and rivers. Lakes are characterised by the conditions in the catchment and consist of different types ranging from oligotrophic to dystrophic. The upper parts of the catchments are relatively nutrient-poor. Streams and rivers often have swiftly flowing, clear water and channels formed in sand, gravel and boulders. Further downstream and in slow-flowing reaches there is fine-grade material and soft bottoms. In these reaches, the water is generally more nutrient rich. Most of the largest rivers are impounded and regulated for hydropower. From the mid-180os and for more than 100 years most streams and rivers in northern and central Sweden were channelized for timber-floating. Some of those watercourses are now being restored to favour biodiversity and retention capacity.

In Finland freshwater habitats cover almost $34,000 \mathrm{~km}^{2}$ (Ahokumpu et al. 2014). Most Finnish rivers were cleared of rocks to facilitate the floating of timber in the late 19th and early 2oth centuries, and most large rivers were dammed for hydropower between 1930 and 1980. Water level regulation affects more than one third of Finland's lakes by area, and a much larger proportion of the water volume, since most of the larger watercourses are regulated. One of the greatest changes regarding inland waters has been the clearing and straightening of small streams and brooks to improve forest drainage. Many springs have also been altered, mainly for water supply. In addition to altering the courses of streams, forestry practices have also affected the biodiversity of small water bodies by changing the light conditions and microclimates of these habitats (Ahokumpu et al. 2014). 
In Norway freshwater habitats cover almost 34,000 km² (Norway's Fourth National Report to the convention on Biological Diversity 2009). Physical encroachment is the most important threat to freshwater habitats. This includes pond fill-in and channelling of streams for agricultural purposes and watershed regulation for hydropower development, causing water level fluctuations, altered current conditions, drying out, and sedimentation. Dredging and substrate depositions in the shore zone have also impacted the freshwater habitats. Pollution is also a serious threat to this ecosystem. River deltas are negatively impacted by agriculture, road building, river regulation, and industrial development (Norway's Fourth National Report to the convention on Biological Diversity 2009).

In Iceland freshwater habitats cover almost 2,200 km² (Arnalds 2015). Several of the large rivers in Iceland have been dammed for hydropower and presently some $20 \%$ of the available hydropower is utilised (Orkustofnun 2017). In total, reservoirs cover around $250 \mathrm{~km}^{2}$ (Hallsdóttir et al. 2013). The effects on the environment are mostly in the highlands where vegetation usually is scarce except in valleys and areas where water is present. Among the detected environmental impacts of such reservoirs on biological diversity are disappearance of freshwater ecosystems, disappearance or alteration of waterfalls and reduced sediment transportation in glacial rivers downstream (Ministry for the Environment and the Icelandic Institute of Natural History 2001). 
Figure 7: Development of "green energy", like hydropower, causes large ecosystem destruction and degradation. In this project at Svartevassdammen, South-west Norway, the hydropower company aims at compensating some of the impact by creating a new wetland area in the stone quarry

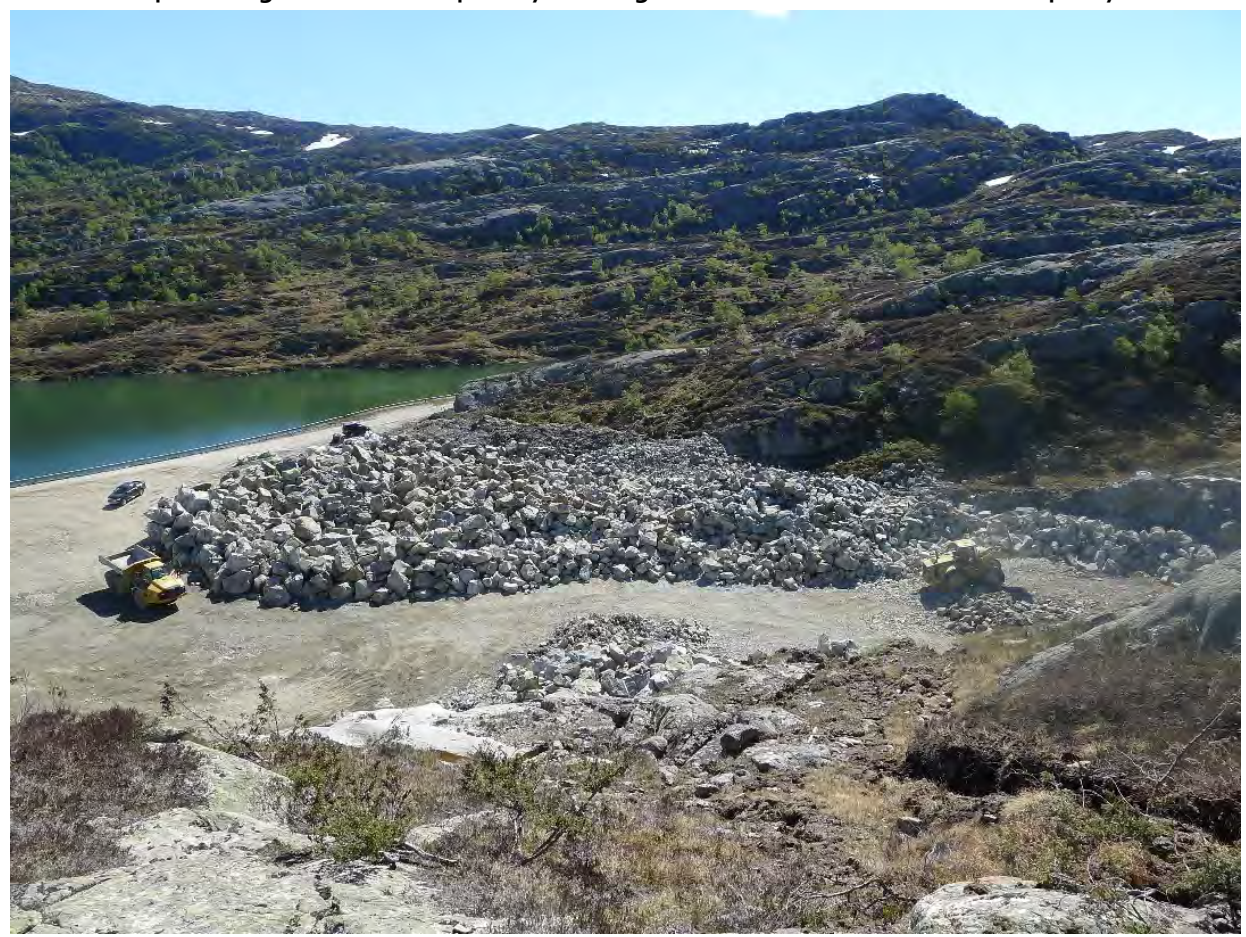

Photo: Dagmar Hagen.

In Denmark freshwater habitats cover almost $850 \mathrm{~km}^{2}$ (Ejrnæs 2009). Denmark's many watercourses are affected by straightening and, in many cases, also by heavy-handed maintenance and deposition of nutrients and sediment. Many stretches of the watercourses have an unnatural, unvaried course. A few watercourses run in pipes for parts of their course (Danish Ministry of the Environment 2014). The main threats to Danish lakes come from the introduction of agricultural nutrients and sewage. Over time, an unknown number of ponds have been drained or reclaimed for agriculture and an unknown number of new ponds have been dug (Fourth Country Report to CBD Denmark 2010). 
In all the Nordic countries freshwater habitats have been seriously degraded. Rivers have been cleared of coarse sediment and straightened to facilitate the floating of timber in the late 19th and early zoth centuries. Later on, most rivers were developed for hydropower. Rivers are also channelized or constrained with levees in order to protect land or roads or other property. In areas with intensive agriculture or in urban areas watercourses are largely affected by straightening and, in many cases, also by heavy-handed maintenance and deposition of nutrients and sediment. Many stretches of the watercourses have an unnatural course and may partly run in artificial channels or pipes. It can be assumed that the ecological resilience of Nordic freshwater habitats in general is significantly reduced and in some areas seriously damaged. The potential of this habitat type to retain water and to mitigate floods is likely to be seriously reduced.

FARMLAND: A significant part of the Nordic countries is farmland. This habitat is most extensive in Denmark, Finland and Sweden.

In Denmark the total area of farmland is $28,000 \mathrm{~km}^{2}$ (Danish Ministry of the Environment 2014). During the past three decades, Danish agriculture has changed significantly in terms of production patterns and structure. The main trend has been a development towards fewer and larger holdings with more intensified and specialised production. These changes have left a more monotonous landscape and led to a significant decrease in many nature types, including semi-cultural types. A fragmentation of natural habitats in the landscape has also taken place. In recent years this negative trend for biodiversity has been somehow reversed due to marginalisation of agricultural land, nature restoration and the removal of "perverse" economic incentives for activities such as draining and land reclamation (Ministry of Environment and Energy 1998).

In Sweden farmland covers almost 35,000 km² (Statistiska Centralbyrån 2017). The status of most of the habitats and species reported on in agricultural ecosystems in Sweden is not favourable. Due to fundamental structural changes in agriculture the area of semi-natural pastures and meadows has decreased markedly and the management of the remaining such ecosystems is often insufficient for preserving the values of these systems. These changes have also caused a severe loss of ecological functionality and diversity in the agricultural landscape. The structural changes are still on-going in a way that is detrimental to the agricultural ecosystems (Fifth National Report to the Convention on Biological Diversity-Sweden 2014). 
In Finland farmland covers around $21,000 \mathrm{~km}^{2}$ (Ahokumpu et al. 2014). Finland's farmlands are situated mainly in the southern and western parts of the country. Traditional rural biotopes such as dry meadows and wooded pastures are the most species rich and, at the same time, most threatened types of farmland habitats. Historically the biggest changes affecting farmland biodiversity have been the dwindling of many traditional agricultural practices related to low-intensive animal husbandry. Modern agriculture relies, instead, on intensive land use (Ahokumpu et al. 2014).

In Norway farmland covers around 12,000 km² (Norway's Fourth National Report to the Convention on Biological Diversity 2009). In Norway the number of farms has been reduced from almost 200 thousand in 1959 to close to 40 thousand in 2015, and the use of large outfields has changed or ceased and these areas have often become overgrown with woodland in the absence of management (Rognstad et al. 2015). This development has occurred through a so-called "polarisation" of agriculture where areas of intensive production are further intensified (Norway's Fourth National Report to the Convention on Biological Diversity 2009). Lowland floodplains have also been intensively drained and converted to cropland and rivers channelized for the same purpose (Rognstad et al. 2015).

In Iceland farmland covers around $1,300 \mathrm{~km}^{2}$ (Hallsdóttir et al. 2013). Around $90 \%$ of the cultivated area is permanent grass fields, and the remaining $10 \%$ are roughly divided equally between barley production and green fodder (Helgadottir et al. 2013). Most land in Iceland is open to grazing, and grazing pressure on uncultivated land has affected the vegetative cover and changed the species composition in many areas (Ministry for the Environment and the Icelandic Institute of Natural History 2001).

The general trend in agriculture in the Nordic region is concentration and intensification of farming. Small farms have largely disappeared and the remaining farms are larger and more specialised than before, and are characterised by intensified land-use practices such as subsurface drainage. Areas of semi-natural pastures and meadows have also decreased markedly, which has caused a severe loss of ecological functionality in the agricultural landscape. More intensive farming is likely to increase pressure on the land and reduce ecological resilience of agricultural land towards natural hazards, partly due to destruction of the mosaic of well-connected early and late successional habitats, which are important to preserve the capacity of these ecosystems to recover from small- and large-scale disturbances (Bengtsson et al. 2003).

SUMMARY: Degradation and fragmentation of important habitats in the Nordic countries is likely to have reduced or even seriously damaged their ecological resilience. 
Although the Nordic boreal areas have largely retained their native species, this habitat is significantly altered and fragmented due to commercial forest management. This applies also to the nemoral forests which are further affected by extensive plantings of introduced conifers. The Nordic wetlands and peatlands are disturbed and fragmented due to intensive draining and the freshwater ecosystems have been seriously degraded. This is of significant concern. In a highly fragmented and intensively managed landscape, the potential of ecosystems to reorganize, recover and turn back to their previous state is reduced, which increases the probability that ecological surprises may occur (Bengtsson et al. 2003). This needs to be addressed by, for example, increased restoration efforts of disturbed ecosystems. Nordic farmland is under growing pressure due to intensification of agriculture during recent decades. This is likely to reduce the resilience of farmland towards natural hazards and there is a need to build up resilience in agriculture (Lin 2011). The vulnerability of Nordic alpine habitats to disturbance and natural hazards must also be stressed. Although large areas in the alpine zone are still relatively pristine, there is increasing pressure from tourism and physical encroachments.

The consequences of reduced ecological resilience are most serious in areas with dense populations, but the roots of disasters may lie in degraded and exploited upland areas. This reduction in the inherent ability of ecosystems to mitigate the impacts of natural hazards can have considerable consequences for Nordic societies. The result is that hazards, which might have been harmless when the ecological resilience of ecosystems was intact, may turn out to be a serious disaster. 


\section{Building up ecosystem resilience towards specific hazards}

The ERMOND network addressed the question: how can we use Eco-DRR to mitigate the impacts of natural hazards in the Nordic countries, through case studies on potential build-up of ecosystem resilience towards following major hazards: (a) floods, (b) wind throw in forests and (c) tephra deposition during volcanic activity. These natural hazards were chosen as they rank among the highest natural hazards in the Nordic countries in terms of the damage they cause (Agustsdóttir et al. in manuscript). These case studies were primarily conducted as desk studies supported by workshops.

\subsection{Ecological resilience towards floods}

Floods are natural phenomena that occur frequently in all the Nordic countries. When floods reach the maximum levels likely to occur, they can be referred to as extreme floods. Human history includes many examples of such extreme floods, often with many casualties, substantial geomorphic change and damage of infrastructure as a consequence. Floods can result both from large amounts of water flowing in streams and rivers and from high sea levels or storm surges. One of the best examples of extreme floods is debris floods caused by an immense mobilisation of melt water following volcanic eruptions in glaciated areas, a phenomenon occurring now and then in Iceland. Such floods are examples of natural hazards. While a flood induced by a volcanic eruption is a completely untamed natural hazard, there are also cases when human impacts have increased the frequency and severity of flood hazards. Such impacts include urbanisation, floodplain development, deforestation, field drainage, and agricultural intensification. The human response to such floods has been to build defence structures, to regulate the flow, and/or to relocate human settlements. Climate change is also expected to increase flood risks in some regions, particularly as a result of heavy rainstorm events. Such risks may require further protection against floods, or a change of mind set, i.e. "living with 
floods" rather than "combating floods". Nordic flood risk governance needs revision; instead of modifying channels even more, ecosystems in catchments can be restored to increase their retention capacity, thus reducing future flood risks further downstream. Such retentive restoration actions can be located to uplands and riparian zones, as well as in stream channels. Along seashores, restoration should aim for increasing storm surge protection.

Figure 8: Flooding is a natural phenomenon but may become a hazard if people settle too close to the river. Mårdsele rapids in the Vindel River, northern Sweden

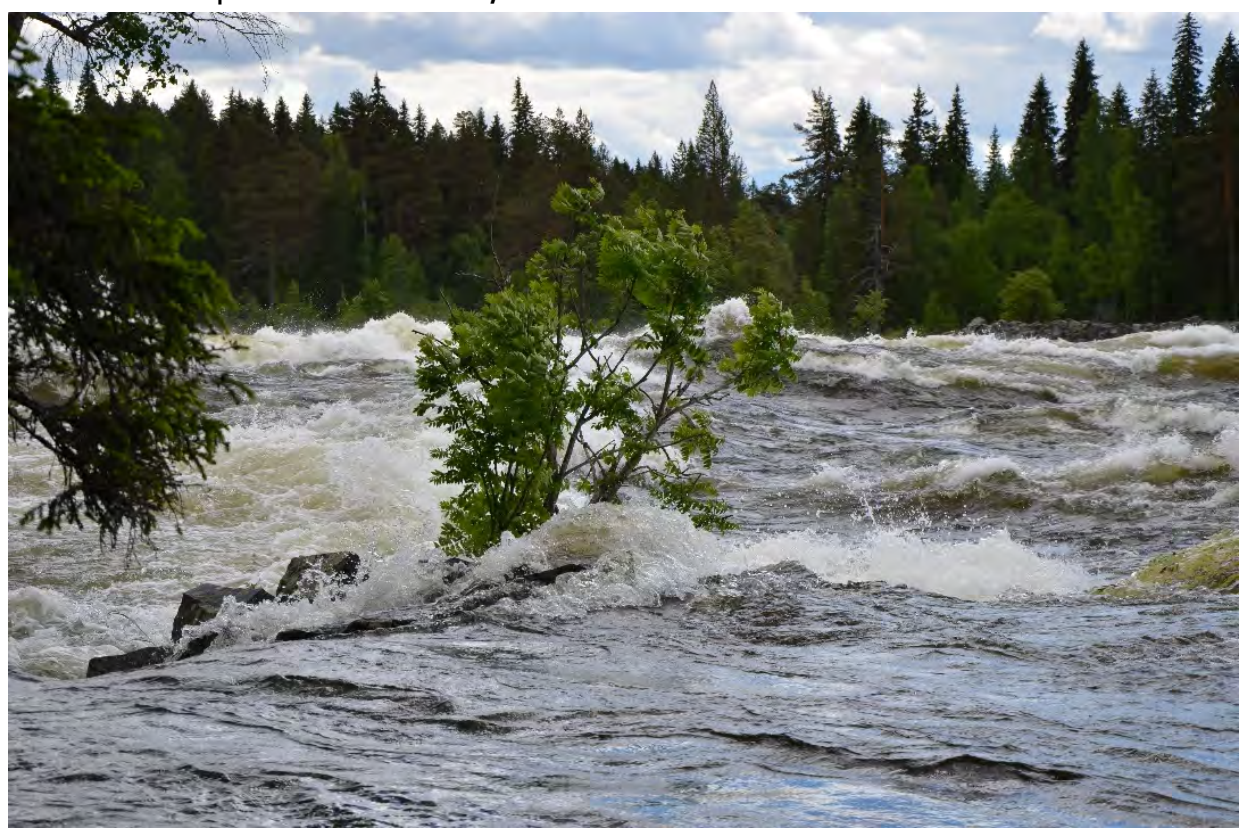

Photo: Christer Nilsson.

Under the ERMOND project we reviewed the literature dealing with ecological resilience towards floods (Nilsson et al. in review). In this review, we identified the stream and river types that are disposed to hazardous floods; we identified contemporary ecological restoration practices, and evaluated their ability to mitigate hazardous floods downstream of restored areas. We also discussed whether current restoration practices would work under the flow changes anticipated in the future. Our study reviewed the Nordic countries regarding the following questions: (1) What types 
of watercourses are most susceptible to hazardous floods? (2) What ecological restoration practices can affect flooding and how efficient are they in increasing resilience against hazardous floods? (3) What future changes in mean annual discharge, flood frequency, timing and magnitude can be foreseen? (4) Will there be a need for modified land use and restoration practices with the expected changes in climate and flooding regimes? (5) Are there restoration practices outside the Nordic countries that would be applicable in the Nordic countries for the forecast scenarios of climate change? Initially, we also wanted to study how restoration affected hydrology, but concluded that poor access to relevant data made this impossible.

The Nordic countries have many types of streams and rivers, in urban, agricultural and forested landscapes, that are vulnerable to hazardous floods. Ecological restoration can moderate flooding in these watercourses and reduce flood peaks downstream of restoration sites by making use of retentive measures in the catchment, riparian zone and in-stream channel. With further climate change, mean annual discharge is likely to increase in many streams and rivers in the northern parts of the Nordic countries, although with more restricted water-level variations. A higher frequency of extreme rain storms may, however, lead to more large floods in the future, especially in small streams (Nilsson et al. in review). A proactive approach to large floods in the future, with a focus on the sustainability and services of free-flowing river ecosystems, means that certain land use practices have to move away from the most flood prone areas. We did not find any relevant international restoration practices that merited introduction into the Nordic countries. In general, however, we advocate sharing information among countries on how ecological restoration in flood mitigation among countries can provide mutual benefits for all.

\subsection{Ecological resilience of forests towards wind-throw}

Storms and wind-throw in forest are natural phenomena that occur frequently in all the Nordic countries. Human history includes many examples of severe wind-throw in forests. Large recent examples are the 1999 December storm in Denmark where $3,600,000 \mathrm{~m}^{3}$ of timber, almost corresponding to one year's normal cutting in Denmark, were blown down and the storm named Gudrun in 2005 in Southern Sweden responsible for blow down of $70,000,000 \mathrm{~m}^{3}$ timber corresponding to two years of cutting in the region. Wind-throw is the most important hazard related to forestry in 
subboreal and nemoral areas. At first, large values are lost due to increased harvesting cost and even destruction of the timber during the wind-throw. At the same time this enhances biodiversity and the amount of dead wood in forests. Later, indirect ecological consequences like reduced "forest climate" and outbreak of bark beetle attacks cause further economic loss, although seldom valued.

Forest ecosystem stability relies on two distinct aspects, resistance of the forest to disturbances like wind-throw, and the capacity to recover from a disturbance, i.e. the resilience of the system. The concepts of resistance and resilience are often combined under the term resilience. When it comes to storm damage and wind-throw it makes sense to distinguish between the capacity to stand up to a storm, i.e. resistance, and to recover from the damage if the resistance was insufficient, i.e. resilience.

Most research has focused on the forest resistance and subsequent problems like beetle attacks and economically related problems, whereas very little has focused on: (a) the kind of forest that establishes by itself after wind-throw, (b) what kind of services the new forest can provide, and (c) what kind of restoration interventions the forester can make in order to increase the functionality and ecosystem service provision by the "new forest" coming after a wind-throw. Climate change is expected to increase windthrow damage in some regions, including the Nordic. 
Figure 9: Sitka spruce after a wind-throw in Stálpastadir, West Iceland, during a gale 14.3.2015. The trees were ca $20 \mathrm{~m}$ in height and planted in the 1952-57. Storm-fall has been unusual in Iceland, but as forests grow in height the risk of storm fall increases

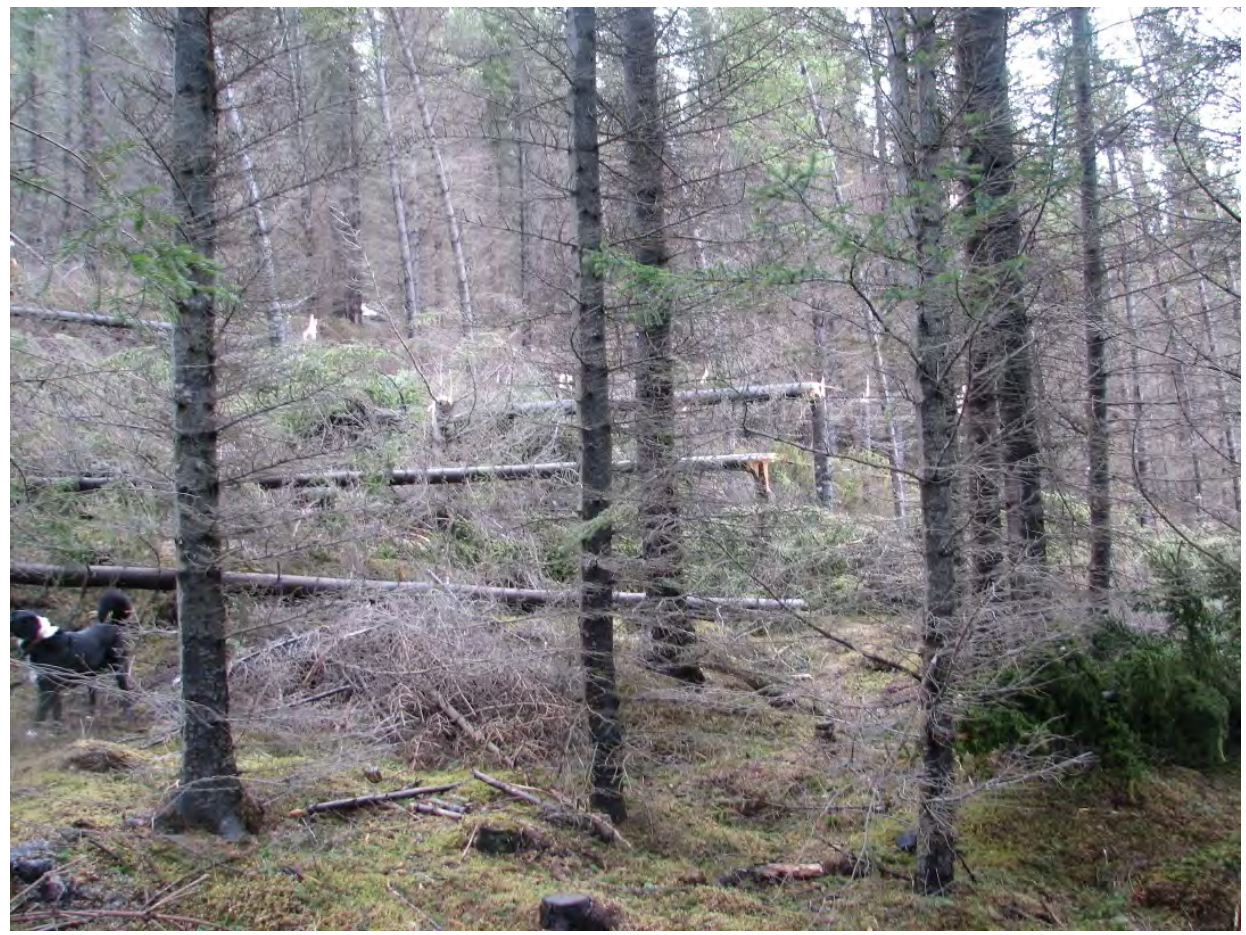

Photo: Valdimar Reynisson.

Under the ERMOND project we focused on the recovery of forests exposed to wind-throw and what the forest manager can do before the storm to improve resilience after the storm (Taeroe, Raulund-Rasmussen et al. in prep.). We identified 9 studies located in the Nordic and Baltic region, all dealing with aspects of forest recovery after wind-throw. To increase the material we supplemented with around 10 Central European cases. We asked questions related to: (1) The recovery rate of the forests, (2) how processes and structures influence the recovery, (3) how structures before the storm event influence the recovery, (4) how forest management after the wind-throw influences recovery, and (5) how the wind-throw affected the successional development. 
Analyses of the case studies are not finalized but as a preliminary we can conclude that forests in our region generally are quite resilient towards wind-throw, but the important question is the quality and the economic value of the recovered forests. It seems that advanced regeneration, soil disturbance and dead wood play an important role in the recovery, especially in the boreal region. In the nemoral region, deer browsing seems to be more important. Often the succession will go back to primary species like birch and rowan.

Generally the case study analyses showed that only limited attention has been put on the natural recovery processes, probably because the traditional forest management actions following wind-throw have been salvage logging and traditional planting. Focusing more on the natural environment like management approaches now being introduced in forestry emphasise the need for a research effort related to natural recovery processes and how to prepare the forests for coming storms by actions aiming at improving the post-wind-throw resilience.

\subsection{Ecological resilience towards deposition and secondary transport of volcanic tephra}

Volcanic eruptions with extensive tephra deposition are a major cause of disasters in Iceland, which threaten ecosystems, human livelihood and health (Ágústsdóttir 2015). After deposition, the tephra can be a long-term source of sandstorms, which can cause extensive soil erosion. Furthermore, the re-distribution of volcanic materials years and decades after the volcanic event can cause hazardous dust pollution which affects human health. Due to widespread deforestation, followed by extreme and extensive land degradation, large areas in Iceland have limited capacity to stop secondary transport of the tephra by wind and water and the release of massive dust clouds.

Mt Hekla is one of the most active volcanoes in Iceland (Höskuldsson et al. 2007). Historical records show that prior to human settlement the area in the vicinity of Mt Hekla was mostly covered by woodlands, which stabilised volcanic tephra and pumice and prevented secondary distribution. Following the settlement, forest clearance and intensive grazing started (Sigurmundsson et al. 2014). This reduced the resilience of the ecosystem towards deposition of volcanic tephra and sand storms, which initiated large-scale soil erosion (Thorarinsdottir et al. 2012). These geomorphological processes are still active in the area, posing a significant threat to ecosystems and neighbouring communities. 
To combat this, a large scale restoration project, Hekluskógar, was initiated in 2007. The project area extends over more than $1,000 \mathrm{~km}^{2}$ (Oskarsson unpublished data) and more than half of it undergoes active erosion and has only sparse vegetation cover (Aradottir 2007). The main objective of the project is to restore the native woodlands in the area in order to increase the resilience of the ecosystem towards deposition of volcanic tephra and prevent secondary distribution of the tephra. Other goals are restoration of ecosystem functions and biodiversity, carbon sequestration, and improved options for future land use. The project was grounded on previous experience from land reclamation and woodland restoration in the area and was planned with a diverse group of stakeholders, using maps of vegetation, soil erosion and land tenure as a basis (Aradottir 2007).

Figure 10: Tephra from the eruption in Eyjafjallajökull in 2010 in Steinsholt South Iceland. Notice that the willows are not affected by the tephra

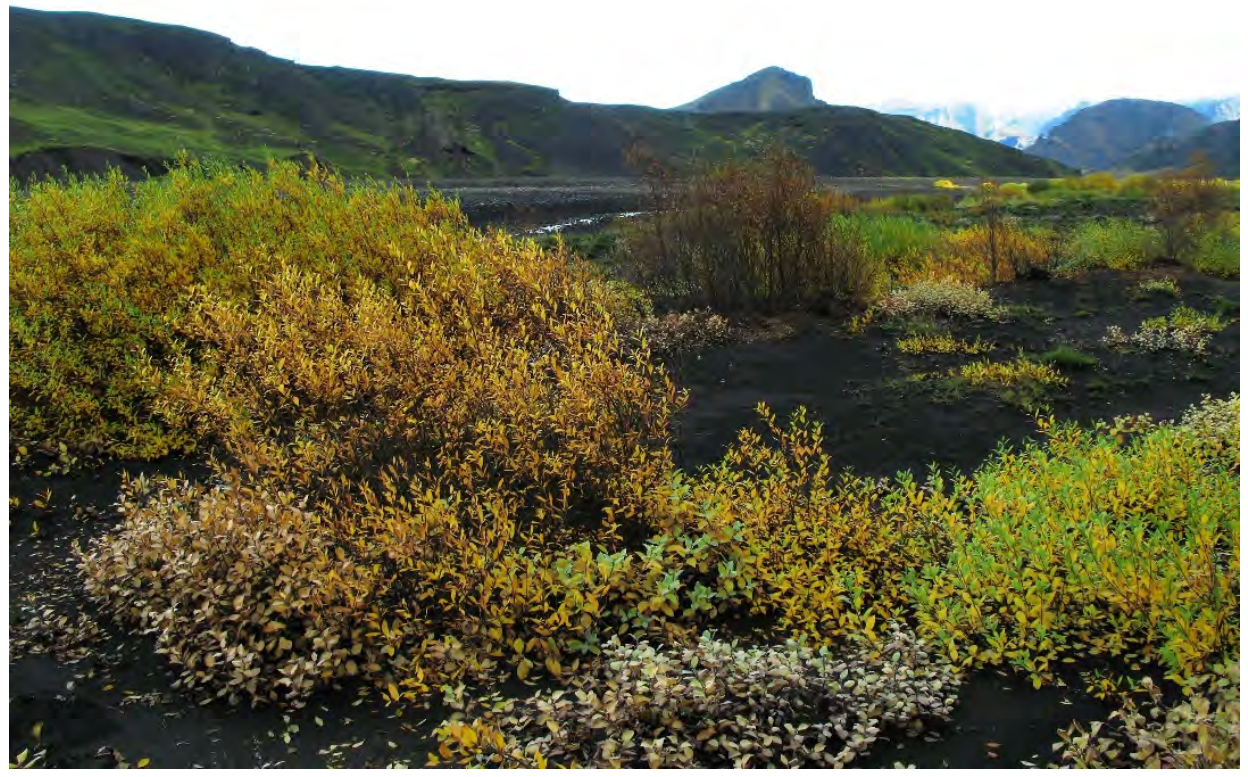

Photo: Ása L. Aradottir. 
Under the ERMOND project a case study was initiated in the Hekluskógar area with the aim to: (a) map the present resilience of ecosystems in the vicinity of Mt Hekla towards tephra fall and secondary distribution of the tephra; $(b)$ improve current strategies used by the Hekluskógar project for restoring the resilience of ecosystems in the area; and (c) serve as a model for similar projects in the vicinity of other major volcanos in Iceland and elsewhere. The case study was co-funded by The Icelandic Avalanche and Landslide Fund as a part of a larger project, FutureVolc, which has the aim to map volcanic hazards in Iceland.

Four ecosystem characteristics were identified as dominant in relation to the resilience of the area towards tephra deposition and secondary distribution of tephra: habitat type; vegetative cover; surface roughness; and surface slope. Mapping based on these factors showed that the vegetation in most of the area is vulnerable towards tephra fall and that secondary distribution of the tephra is likely to occur (Thorarinsdottir et al. 2017). Preliminary results show that 8-10 years after establishing birch in the area the resilience of ecosystems towards tephra deposition has already increased significantly compared to low non-woody vegetation (Ágústsdottir et al. 2016). Studies on the distribution potential of birch and willows show that both species have already started distribution by seed at early age at a significant rate (Aradottir \& Halldorsson in review). Strategic planting of these species and facilitation of their distribution is therefore an inexpensive way to restore woodlands in the area.

We conclude that the low state of ecosystem resilience in the vicinity of Mt Hekla poses a weak point in risk reduction management in the area. We suggest that this should be combatted with extensive, relatively low budget measures based on strategic planting and direct seeding of native birch and willows to facilitate natural colonization and eventually widespread woodland restoration. This could serve as a model for similar projects in the vicinity of other major volcanos in Iceland. 


\section{Integrating Eco-DRR and restoration of degraded ecosystems}

Ecological restoration is a needed and in some cases urgent activity to reverse some of the negative aspects of ecosystem exploitation, and as a tool for future management of the environment. Most explicitly, this has been stated in the Convention on Biological Diversity (CBD) Aichi targets and further in EU biodiversity strategies and national environmental targets (https://www.cbd.int/sp/). All the Nordic countries are Parties of CBD and are committed to the Aichi targets.

The focus and objectives in ecological restoration are diverse, including in situ conservation of populations of rare species, restoration of areas damaged by mining or other economic development, large-scale compensation of expanded infrastructure, and carbon sequestration through forest planting and land reclamation. The increasing focus on ecosystem services in ecological restoration has highlighted a possible conflict between a single target focus when restoration is aimed at only one specific ecological service, on the one hand, and on the other hand a multilevel focus approach including broader and more holistic aims. This can be described as a double challenge, such as when carbon economies (e.g. efforts and actions to capture and store carbon by forest plantations) have negative ecological and economic consequences as biodiversity conservation is not considered, and as a restoration measure can be in direct conflict with protecting biodiversity (see e.g. bio-perversity in Lindenmayer et al. 2012).

The Strategic Plan for Biodiversity 2011-2020, under the CBD, formulates the 20 Aichi Biodiversity Targets (https://www.cbd.int/sp/). Over the last five years, the Aichi targets have had a considerable impact on ecological restoration work worldwide. The targets point at ecological restoration as an important tool and strategy, traditionally for the long-term protection of biodiversity, and recently more openly for the production of ecosystem services (Bullock et al. 2011), including the mitigation of disaster risk from land degradation and climate change (e.g. Estrella and Saalismaa 
2013). The Aichi targets also have a direct impact on policy and current work in the Nordic countries and the EU (e.g. Hagen et al. 2015; Lammerant et al. 2014). The single target that has gained the most attention in this context is Aichi target 15: "by 2020, ecosystem resilience and the contribution of biodiversity to carbon stocks has been enhanced, through conservation and restoration, including restoration of at least 15 per cent of degraded ecosystems, thereby contributing to climate change mitigation and adaptation and to combating desertification". This target has received considerable attention as regards policy, science and management, and also raised some consciousness of restoration among people in general. Much focus has been on the number (the $15 \%$ ) per se. However, the target is very widely formulated, comprising complicated and diverse concepts such as resilience, ecosystem services (carbon stocks, climate change mitigation) and biodiversity. When approaching this target from a wider perspective beyond the counting of percentages, it brings us into the heart of the "double challenge", and illustrates the complications, trade-offs and possible conflicts within Target \#15. In particular, the ecological services approach has put focus on the ecosystem as something to utilize and to benefit from (e.g. de Groot et al. 2013). Consequently, restoration for ecosystem services seems to make it easier to argue for the potential benefits to be gained, and has increasingly become a driver for restoration during recent years. 
Figure 11: Organic soil and vegetation is a limiting factor in alpine areas. Development projects normally have large impact in this ecosystem. By storing and re-use the vegetation during and after development projects the negative impact can be limited, and the recovery will be more successful

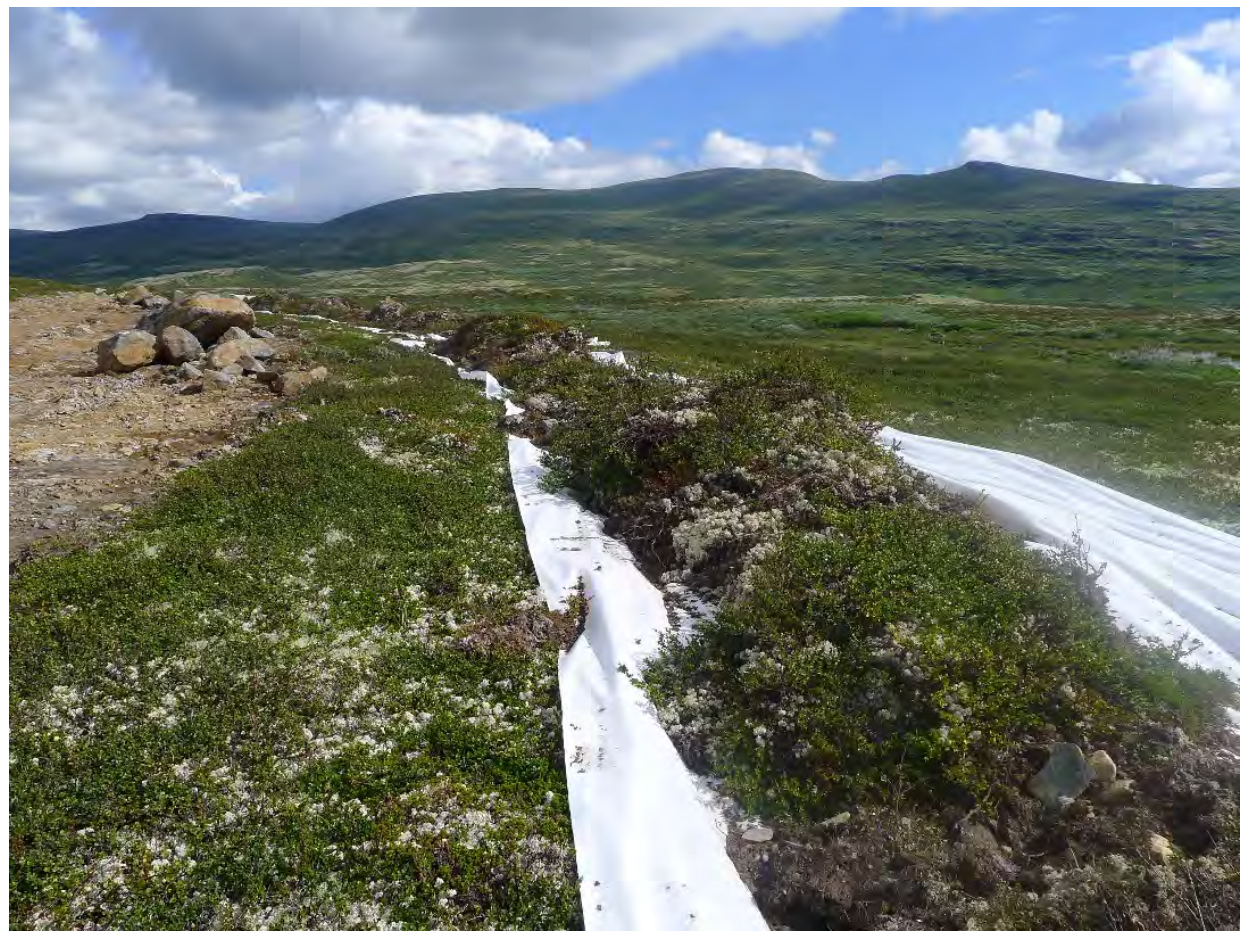

Photo: Dagmar Hagen.

The challenges of ignoring biodiversity when restoring for ecosystem services were addressed in a workshop held in Oslo Research Park on the zrd of December, 2015. The workshop was organized by the Norwegian Institute for Nature Research (NINA) and the Soil Conservation Service of Iceland (SCSI) as a part of the Nordic network project ERMOND. The workshop related to the first aim of the ERMOND project, to "compile an overview of natural disasters in the Nordic region and how ecological restoration actions can be used to mitigate such hazards". Fifteen invited participants from science and management attended the workshop.

The background for the workshop was the increasing focus in recent years on ecosystem services and counting the benefits from ecological restoration, perhaps at 
the cost of biodiversity (the "double challenge"). The aim for the workshop was to discuss if, and how, we should have a more holistic view on ecosystems in ecological restoration to meet global challenges such as land degradation and effects of climate change. In particular, we encouraged discussion on trade-offs, and also liked to touch on some of the consequences of trade-offs within and between society, ecology and the economy when restoring ecosystems.

Figure 12: Restored birch woodland at Bolholt, South Iceland

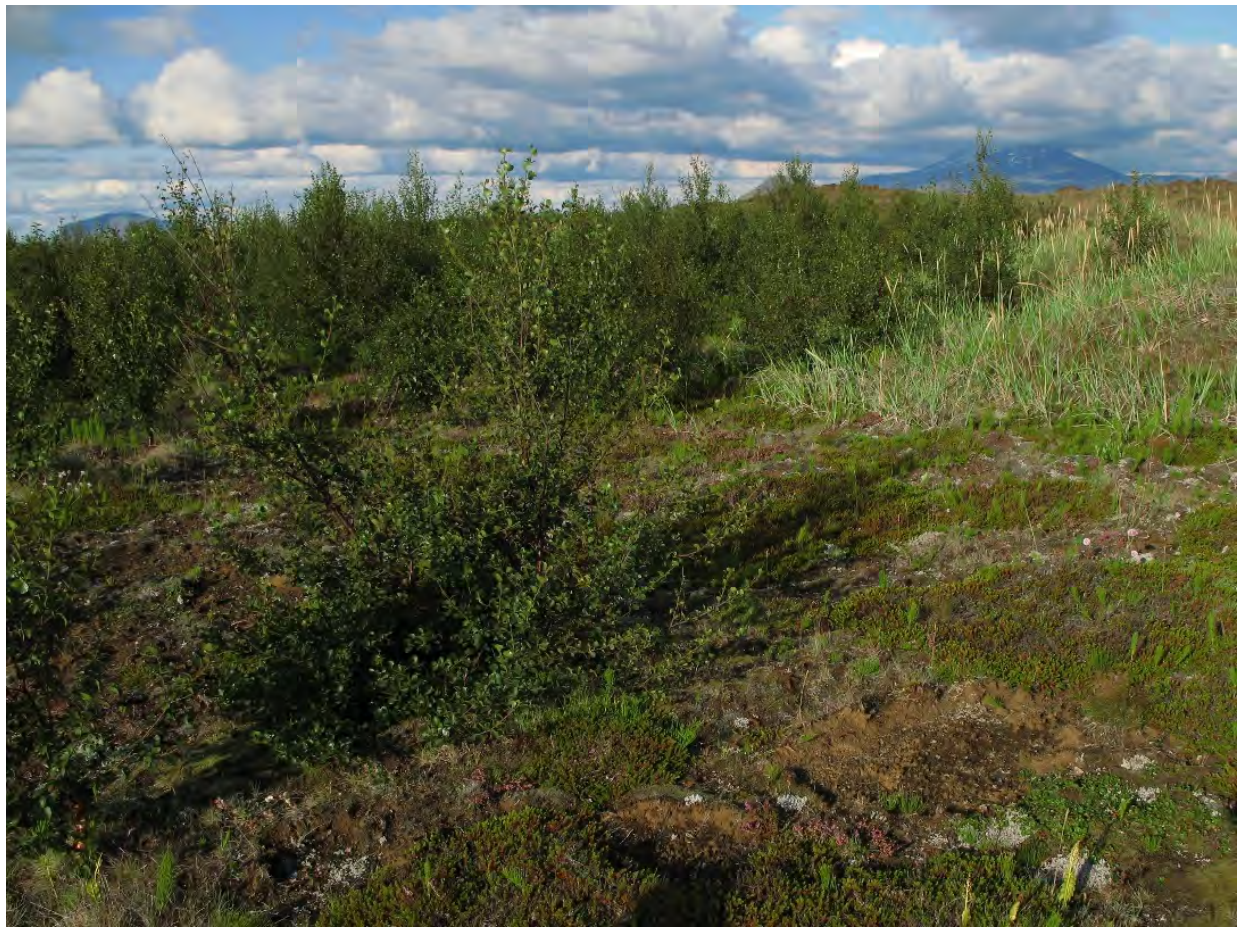

Photo: Ása L. Aradóttir.

Three speakers from different scientific professions were invited to give introductory talks with their perspectives on the possible conflicts and trade-off between ecosystem services and biodiversity, and relate to the increased emphases on ecological restoration. Erik Gómez-Baggethun is a Senior Researcher at the Norwegian Institute for Nature Research (NINA) and a Senior Visiting Research Associate at the University of Oxford. His research covers topics in ecological economics and political ecology, with a focus on 
ecosystem services and environmental governance. Susan Baker is a Professor in Environmental Policy, Cardiff School of Social Sciences and Co-Director at Sustainable Places Research Institute, Cardiff University. Her research focuses on the relations between social and ecological processes, including bringing in issues of governance, viewed from the stance of civic engagement and participation. Anne Tolvanen is a Professor in forest ecology in the Natural Resources Institute Finland (LUKE) and the University of Oulu. Her research focuses on the restoration of boreal forests and peatlands, climate change and disturbance impacts on arctic vegetation, and most recently, on the reconsolidation of multiple land use needs by quantifying and optimizing ecosystem services.

The remaining part of the workshop was organized as discussion, aiming to address the following issues: (a) the relationship between ecosystem services and biodiversity, (b) the relationship between ecosystem services and resilience, and (c) the relationship between biodiversity and resilience. An attempt was made to include in the discussion how ecological restoration can be a tool to deal with these concepts and the links between them.

The workshop highlighted the topic of trade-offs between biodiversity and various ecosystem services, and all three speakers touched on this topic from their different angles. During the discussion it became apparent that there is an interesting link (or even contrast) between trade-offs and win-win solutions. There are always trade-offs between different solutions and services; we will never know them all, and there will always be uncertainties and multiple challenges. We need, however, to know something about trade-offs before taking decisions. The search for win-win solutions might undermine conflicts that are essential and must be dealt with to protect biodiversity, or are win-win solutions simply a matter of time scale? Ecological restoration is a process rather than only a technical tool; and it may also be a political decision. Climate change as a driver for ecological restoration was discussed in the workshop, and it also raised some interesting statements about how this opens the possibility to "grasp the opportunity" to restore ecological function and biodiversity. The strong emphasis on climate change mitigation also gives priority to actions and activities that potentially and likely have an impact on biodiversity. Some activities will fulfil ecological, social and climate goals, while other activities will not. This also raised a discussion about the role and definition of ecological restoration and how closely linked this is to protection of biodiversity. 
Ecosystem degradation is a pronounced problem in the Nordic countries, which has had significant negative effects on important ecosystem services, such as ecosystem resilience and carbon sequestration, as well as biodiversity (Hagen et al. 2013). Restoration with the aim to produce ecosystem services has emphasized the ecosystem as something to use and benefit from. Restoration for ecosystem services thus focuses on the potential benefits, and has increasingly become a driver for restoration during recent years. This can lead to a "fragmented" environmental policy, where opportunities for reaping the full-scale benefits from ecological restoration are missed.

Therefore, the main conclusion from this specific ERMOND network study is that, although the need for restoration of certain ecosystem services is of a high importance, this must not result in a single target focus at the cost of broader and more holistic aims. To accomplish this, projects aiming at enhancing Eco-DRR must be planned in a way that benefits also broader aims of restoration, such as protection and enhancement of biodiversity. 


\section{References}

Ágústsdóttir AM 2015. Ecosystem approach for natural hazard mitigation of volcanic tephra in Iceland: Building resilience and sustainability. Natural Hazards 78, 1669-1691. DOI: 10.1007/s11069-015-1795-6.6

Agustsdottir et al. in manuscript. Ecological restoration and sustainable land management for disaster risk reduction of natural hazards under changing climate in the Nordic region.

Agústsdóttir AM, Bau A, Halldórsson G, and Aradóttir AL 2016. ERMOND-Grógos: Experimental setup estimating the effect of volcanic ash deposition on restored birch woodland vegetation, Hekluskógar, Iceland. Page 97 in: Johannes Kollmann \& Julia-Maria Hermann (eds.) SER Europe Conference 2016: Best Practice in Restoration, August 22-26, Freising, Germany. Chair of Restoration Ecology, Technische Universität München. http://www.roek.wzw.tum.de

Ahokumpu A-L, Auvinen A-P, Pylvänäinen M and von Weissenberg M (eds.) 2014. Ministry of the Environment: Fifth national report to the convention on biological diversity - Finland. https://www.cbd.int/doc/world/fi/fi-nr-05-en.pdf

Aradottir AL 2007. Restoration of birch and willow woodland on eroded areas. Pages 67-74 in: Halldorsson G, Oddsdottir ES and Eggertsson O (eds). Effects of afforestation on ecosystems, landscape and rural development. TemaNord 2007: 508, Reykholt, Iceland, June 18-22, 2005. http://urn.kb.se/resolve?urn=urn:nbn:se:norden:org:diva-2283

Aradottir AL and G Halldorsson in review. Colonization of woodland species during restoration: Propagule or safe site limitation.

Arnalds $\mathrm{O}$ 2013. The Influence of Volcanic Tephra (Ash) on Ecosystems. Advances in Agronomy, 121, 331-380. http://dx.doi.org/10.1016/B978-0-12-407685-3.00006-2

Arnalds $\mathrm{O}$ 2015. The Soils of Iceland. World Soils Book Series, Springer, Dordrecht, the Netherlands. http://www.springer.com/environment/soil+science/book/978-94-017-9620-0

Arnalds Ó, Guðmundsson J, Óskarsson H, Brink SH and Gísladóttir FÓ 2016. Icelandic Inland Wetlands: Characteristics and Extent of Draining. Wetlands, 36 (4), 759-769. https://doi.org/10.1007/s13157-016-0784-1

Bengtsson J, Nilsson SG, Franc A, and Menozzi P 2000. Biodiversity, disturbances, ecosystem function and management of European forests. Forest Ecology and Management 132: 39-50. https://doi.org/10.1016/S0378-1127(00)00378-9

Bengtsson J, Angelstam P, Elmqvist T, Emanuelsson U, Folke C, Ihse M, Moberg F and Nyström M 2003. Reserves, Resilience and Dynamic Landscapes. Ambio Vol. 32 No. 6: 389-396. https://doi.org/10.1579/0044-7447-32.6.389

Bullock JM, Aronson J, Newton AC, Pywell RF, and Rey-Benayas JM 2011. Restoration of ecosystem services and biodiversity: Conflicts and opportunities. Trends in Ecology and Evolution 26, 541-549. http://dx.doi.org/10.1016/j.tree.2011.06.011 
CRED CRUNCH 2011. "Disaster Data: A Balanced Perspective". CRED Crunch No. 23, February. Available at

http://reliefweb.int/sites/reliefweb.int/files/resources/F7E6E30438715736C125784Co04D2F49-

Full_Report.pdf. Accessed 11 March 2017.

Danish Ministry of the Environment 2014.5th Danish Country Report To the Convention on

Biological Diversity. https://www.cbd.int/doc/world/dk/dk-nr-05-en.pdf

Danish Nature Agency. http://www.klimatilpasning.dk/kommuner/kortlaegning-til-brug-for-

klimatilpasning/den-kommunale-risikokortlaegning.aspx. Accessed February 18, 2016 (In Danish).

De Groot RS, Blignaut J, Van Der Ploeg S et al. (2013). Benefits of Investing in Ecosystem

Restoration. Conservation Biology. http://dx.doi.org/10.1111/cobi.12158

Eggertsson Ó, Stabbetorp, and Skovsgaard J 2008. History of afforestation in the Nordic countries. Pages 16-27 in: Halldorsson G, Oddsdóttir ES and Sigurdsson BD (eds.)

AFFORNORD - Effects of Afforestation on Ecosystems, Landscape and Rural Development.

TemaNord 2008:562.

Ejrnæs R 2009. Notat til By og Landskabsstyrelsen med udkast til kapitel 1 til 4. Landerapporten til CBD om tilstand, udvikling og trusler for Danmarks biodiversitet. Chapter I: Overview of

Biodiversity Status, Trends and Threats in Denmark (In Danish).

http://pure.au.dk/portal/files/17886698/4.LanderapportBiodiv_notat.pdf

Estrella M and Saalismaa N 2013. Ecosystem-based DRR: An overview. Page 26-47 in: Renaud, FG, Sudmeier-Rieux, K and Estrella, M. (eds.) The Role of Ecosystems in Disaster Risk Reduction. United Nations University Press.

Fifth National Report to the Convention on Biological Diversity - Sweden 2014. https://www.cbd.int/doc/world/se/se-nr-05-en.pdf

Finnish Statistical Yearbook of Forestry 2014. Finnish Forest Research Institute. Web page: http://stat.luke.fi/sites/default/files/vsk14_koko_julkaisu.pdf

Forests and Forestry in Sweden 2017. http://www.skogsstyrelsen.se/Global/upptackskogen/Presentationsmaterial/Forests-and-Forestry-in-Sweden_2015.pdf Accessed on March 17, 2017.

Fourth Country Report to CBD - Denmark, 2010. https://www.cbd.int/doc/world/dk/dk-nr-04-en.pdf

Garne TW, Ebeltoft M, Kivisaari E, and Moberg S 2013. Weather related damage in the Nordic countries, Tech. rep.

http://www.fkl.fi/materiaalipankki/tutkimukset/Dokumentit/Weather_related_damage_in_th e_Nordic_countries.pdf

Gencer EA 2013. The Impact of Globalization on Disaster Risk Trends: A Macro- and Urban Scale Analysis. Background Paper prepared for the Global Assessment Report on Disaster Risk Reduction 2013. UNISDR, Geneva, Switzerland.

http://www.preventionweb.net/english/hyogo/gar/2013/en/bgdocs/Gencer,\%202012.pdf

Gunnarsson U and Löfroth M 2014. The Swedish Wetland Survey-Compiled Excerpts from The National Final Report. Swedish Environmental Protection Agency. https://www.naturvardsverket.se/Documents/publikationer6400/978-91-620-66185.pdf?pid=13166 
Hagen D, Lindhagen A, Päivinen J, Svavarsdóttir K, Tennokene M, Klokk T and Aarønæs MS 2015. The Nordic Aichi restoration project: How can the Nordic countries implement the CBD target on restoration of 15\% of degraded ecosystems within 2020? TemaNord 2015:515. Nordic Council of Ministers. http://dx.doi.org/10.6027/TN2015:515

Hagen D, Svavarsdottir K, Nilsson C, Tolvanen AK, Raulund-Rasmussen K, Aradóttir ÁL, Fosaa $A$ and Halldorsson $G$ 2013. Ecological and social dimensions of ecosystem restoration in the Nordic countries. Ecology and Society 18(4): 34, http://dx.doi.org/10.5751/ES-05891-180434 Hagen et al. in prep. The risk of ignoring biodiversity when restoring ecosystem services. Halldórsson G, Aradóttir ÁL, Fosaa AM, Hagen D, Nilsson C, Raulund-Rasmussen K, Skrindo AB, Svavarsdóttir K and Tolvanen A 2012. Restoration of Damaged Ecosystems in the Nordic Countries. TemaNord, 2012:558. Nordic Council of Ministers, Copenhagen, 65 pp.

Halldorsson G, Sigurdsson BD, Hrafnkelsdottir B, Oddsdottir ES, Eggertsson O and Olafsson E 2013. New arthropod herbivores on trees and shrubs in Iceland and changes in pest dynamics: A review. Icelandic Agricultural Sciences, 26, 69-84.

Hallsdóttir BS, Wöll C, Guðmundsson J, Snorrason A, Pórsson J 2013. Emission of green-house gases in Iceland from 1990 to 2011 National Inventory Report 2013. UST-2013:06. Environment Agency of Iceland.

http://unfccc.int/national_reports/annex_i_ghg_inventories/national_inventories_submissions /items/7383.php

Harjanne A, Pagneux E, Jørgensen LF, Perrels A, Van der Keur P, Nadim F, Rød JK, Raats E 2016. Resilience to natural hazards: An overview of institutional arrangements and practices in the Nordic countries. NORDRESS WP6.1 report.

Helgadottir A, Eythorsdottir E, Johannesson T 2013. Agriculture in Iceland - a grassland based production. Grassland Science of Europe 18:30-43.

Henriksen S and Hilmo O (eds.) 2015. Norsk rødliste for arter 2015 (Norwegian red list for species). Artsdatabanken, Norge (In Norwegian).

Hjartarson Á 1995. Á Hekluslóđum. Árbók Ferđafélags Íslands (In the vicinity of Mt. Hekla. The Yearbook of the Icelandic Travellers Association). Ferðafélag Íslands, Reykjavík, 257 pp (In Icelandic).

Hoffmann CC and A Baattrup-Pedersen 2006. Re-establishing freshwater wetlands in Denmark. Ecological Engineering 30 (2): 157-166. https://doi.org/10.1016/j.ecoleng.2006.09.022

Huppert HE and RSJ Sparks 2006. Extreme Natural Hazards: Population Growth, Globalization and Environmental Change. Phil. Trans. R. Soc. A (2006) 364, 1875-1888

https://doi.org/10.1098/rsta.2006.1803

Höskuldsson Á, Óskarsson N, Pedersen R, Gronvold K, Vogfjord K and Ólafsdóttir R 2007. The millennium eruption of Hekla in February 2000. Bulletin of Volcanology, 70(2): 169-182.

https://doi.org/10.1007/s00445-007-0128-3

http://biodiversity.europa.eu/maes/maes-digital-atlas

http://en.ilmatieteenlaitos.fi/open-data-manual

http://en.vedur.is/avalanches/imo/

http://en.vedur.is/earthquakes-and-volcanism/volcanic-eruptions/

http://ermond.land.is 
http://ermond.land.is/news-and-events/nordbio-final-meeting-minding-the-future/

http://ermond.land.is/news-and-events/ser2016/

http://icelandicvolcanoes.is/

http://inonkart.miljodirektoratet.no/inon/kart

http://nordbio.org/

http://paikkatieto.ymparisto.fi/tulvakartat/Html5Viewer_2_7/?locale=fi-FI

https://www.cbd.int/sp/

https://www.cbd.int/reports

http://www.environment.fi/floodmaps

http://www.metla.fi/ohjelma/vmi/vmi-moni-en.htm

http://www.matis.is/nordtic/nr/3974

http://www.nordregio.se/Global/Events/Events\%202014/Nordregio\%2oForum\%202014/Nordre gio\%20Forum\%202014\%2oprogramme_14.pdfSER

http://www.skogoglandskap.no/kart/kilden

Imeson A 2012. Desertificaton, land degradation, and sustainability. Paradigms, processes, principles and policies. Wiley-Blackwell, Chichester.

IPCC 2007. Climate change 2007: Impacts, adaptation and vulnerability. Contribution of working group ii to the fourth assessment. Report of the intergovernmental panel on climate change. Cambridge University Press.

IPCC 2012. Summary for Policymakers, pages 1-19. Managing the Risks of Extreme Events and Disasters to Advance Climate Change Adaptation. A Special Report of Working Groups I and II of the Intergovernmental Panel on Climate Change. Cambridge University Press, Cambridge, UK, and New York, NY, USA, pp. 1-19. Cambridge University Press, Cambridge, UK and New York, NY, USA.

Lammerant J, Peters R, Snethlage M, Delbaere B, Dickie I and Whiteley G 2014. Implementation of 2020 EU Biodiversity Strategy: Priorities for the restoration of ecosystems and their services in the EU. Report to the European Commission. ARCADIS (in cooperation with ECNC and Eftec). http://ec.europa.eu/environment/nature/biodiversity/comm2006/pdf/2020/RPF.pdf

Lin BB 2011. Resilience in agriculture through crop diversification: Adaptive management for environmental change. BioScience 61: 183-193. https://doi.org/10.1525/bio.2011.61.3.4

Lindenmayer BN, Hulvey KB, Hobbs RJ, Colyvan M, Felton A, Possingham H, Steffen W, Wilson $K$, Youngentob $K$ and Gibbons $P$ 2012. Avoiding bio-perversity from carbon sequestration solutions. Conservation Letters 5: 28-36. https://doi.org/10.1111/j.1755-263X.2011.00213.x

Millennium Ecosystem Assessment 2005. Ecosystems and Human Well-being: Synthesis. Washington, DC: Island Press.

Ministry of the Environment 2010. Fourth National Report on the Implementation of the Convention on Biological Diversity in Finland. Ministry of the Environment, Helsinki, ISBN 978952-11-3713-6.

Ministry of Environment and Energy 1998. Denmark's first national report to the Convention on Biological Diversity. https://www.cbd.int/doc/world/dk/dk-nr-01-en.pdf 
Ministry of Environment and Food of Denmark 2017. http://eng.svana.dk/nature/forestry/ Accessed on March 17, 2017.

Ministry for the Environment and the Icelandic Institute of Natural History 2001. National Report to the Convention on Biological Diversity.

https://www.umhverfisraduneyti.is/media/vidhengi/wppo437.html/Biodiversity\%2oReport\%2 olceland.pdf

Moen A 1995. The Norwegian national plan for mire reserves: Methods, criteria and results. Gunneria 70: 156-176.

Nadim F, Schack Pedersen SA, Schmidt-Thomé P, Sigmundsson F, and Engdahl M 2008. Natural hazards in Nordic Countries. Episodes, Vol.31, 176-184.

Nature Index of Norway 2015. http://www.naturindeks.no/Ecosystems/skog

Nilsen EB and Strand O 2017. Populasjonsdynamiske utfordringer knyttet til fragmentering av villreinfjellet. NINA Temahefte 70. $51 \mathrm{~s}$. (In Norwegian).

Nilsson C, Riis T, Sarneel JM, and Svavarsdóttir K. in manuscript. Freshwater Floods as Natural Hazards and Ways to Cope with Them by Restoring Nature.

Norklima. Natural disasters - is your municipality vulnerable? The Research Council of Norway. http://www.forskningsradet.no/prognett-

norklima/Nyheter/Natural_disasters_is_your_municipality_vulnerable/1253984593679\&lang =en Accessed February 18, 2016.

Norway's Fourth National Report to the Convention on Biological Diversity 2009. https://www.cbd.int/doc/world/no/no-nr-o4-en.pdf

Nytjaland 2017.

http://lbhi.maps.arcgis.com/apps/webappviewer/index.html?id=227b358de2ec4738b9d51c8e8 6457cod Accessed 12 March 2017.

Olsen E 2014. Atlas til heim og skúla (Faroes Atlas). Nám, Tórshavn 2014. ISBN 978-99918-2-165-8.

Orkustofnun 2017. http://www.orkustofnun.is/vatn/vatnsafl/ Assessed 28 March 2017. (In Icelandic).

Óskarsson $\mathrm{H}$ 2011. Vistheimt á vegum Votlendisnefndar (Ecological restoration projects sponsored by the Wetland Committee).Page 54-55 in: Aradóttir and Halldórsson (eds.) Vistheimt á Íslandi (Ecological restoration in Iceland). Landbúnaðarháskóli Íslands og Landgræðsla ríkisins. ISBN 978-9979-881-08-7. (In Icelandic).

Renaud FG, Sudmeier-Rieux K and Estrella M 2013. The Role of Ecosystems in Disaster Risk Reduction. United Nations University Press.

Rognstad O, Løvberget Al and Steinset TA 2016. Landbruket i Norge 2015. Jordbruk-SkogbrukJakt. Statistisk sentralbyrå. ISBN 978-82-537-9427-3 (In Norwegian).

Sakals ME, Innes JL, Wilford DJ, Sidle RC, Grant GE 2006. The role of forests in reducing hydrogeomorphic hazards. Forest Snow Landscape Research. 80, 11-22.

Schmidt-Thomé P (ed.) 2006. Natural and technological hazards and risks affecting the spatial development of European regions. Geological Survey of Finland, Special Paper 42. 167 pp. 
Sidle RC, Ziegler AD, Negishi JN, Nik AR, Siewc R, and Turkelboom F 2006. Erosion processes in steep terrain-Truths, myths, and uncertainties related to forest management in Southeast Asia. Forest Ecology and Management 224, 199-225, https://doi.org/10.1016/j.foreco.2005.12.019

Similä M, Aapala K and Penttilä J (eds.) 2014. Ecological restoration in drained peatlands - best practices from Finland. Metsähallitus Natural Heritage Service. Web page: https://julkaisut.metsa.fi/assets/pdf/lp/Muut/ecolres-peatlands-1.pdf

Sigurmundsson FS, Gísladóttir G, and Óskarsson H 2014. Decline of Birch Woodland Cover in pjórsárdalur Iceland from 1587 to 1938. Hum Ecol. 42:577-590. https://doi.org/10.1007/s10745014-9670-8

Snorrason A 2016. Iceland. Page 451-465 in C. Vidal et al. (eds.) National Forest Inventories Assessment of Wood Availability and Use: ISBN 978-3-319-44015-6, https://doi.org/10.1007/978-3-319-44015-6_24

Snorrason A, Traustason B, Kjartansson BP, Heiðarsson L, Ísleifsson R and Eggertsson Ó 2016. Náttúrulegt birki á Íslandi - Ný úttekt á útbreiðslu pess og ástandi (Natural birch woodlands in Iceland - New inventory of distribution and condition). Náttúrufræðingurinn 86 (3-4), bls. 97111. (In Icelandic).

Sólnes J, Sigmundsson F, Bessason B (eds) 2013. Náttúruvá á Íslandi-Eldgos og jarðskjálftar (Natural hazards in Iceland - Volcanic eruptions and earthquakes). Viðlagatrygging Íslands/Háskólaútgáfan, Reykjavík (In Icelandic).

State of Finland's Forests 2012. http://www.metla.fi/metinfo/sustainability/finnish.htm (Accessed on March 17, 2017).

Statistiska Centralbyrån 2017. http://www.scb.se/hitta-statistik/statistik-efteramne/miljo/markanvandning/markanvandning-enligt-svenska-marktackedatasmd/pong/tabell-och-diagram/marktackedata-2000-riket/ (Accessed on March 17, 2017).

Stjernholm M and Kjeldgaard A 2005. I\&CLC2000 CORINE Land Cover update in Denmark. Final Report to European Commission DG Regio and EEA. National Environmental Research Institute. 43 pp.

Taeroe A, Raulund-Rasmussen K et al. in prep. Forest restoration for increased ecological resilience against windthrow.

Thorarinsdottir EF and Arnalds $\mathrm{O}$ 2012. Wind erosion of volcanic materials in the Hekla area, South Iceland. Aeolian Research 4:39-50. https://doi.org/10.1016/j.aeolia.2011.12.006

Thorarinsdóttir EF, Gísladóttir FÓ, Thorsteinsdóttir AB and Halldórsson G 2017. Kortlagning á áfallapoli vistkerfa i nágrenni Heklu með tilliti til öskufalls. Skýrsla til Ofanflóðasjóðs (Mapping of the ecological resilience of ecosystems in the vicinity of Mt Hekla towards tephra fall. Report to the Icelandic Avalanche and Landslide Fund). The Soil Conservation of Iceland, 42 pp. (In Icelandic with English summary).

Tolvanen A and Kangas K 2016. Tourism, biodiversity and protected areas - Review from northern Fennoscandia. Journal of Environmental Management 169: 58-66.

https://doi.org/10.1016/j.jenvman.2015.12.011

UNEP 2009. The Role of Ecosystem Management in Climate Change Adaptation and Disaster Risk Reduction. UNEP, Copenhagen. 
UNISDR 2013. Global Assessment Report on Disaster Risk Reduction: Revealing Risk, Redefining Development. Geneva, United Nations.

United Nations 2015. United Nations Sendai Framework for Disaster Risk Reduction.

http://www.preventionweb.net/files/43291_sendaiframeworkfordrren.pdf (Ac-cessed 11 March 2017). 



\section{Sammendrag og konklusioner}

Denne rapport beskriver resultaterne af arbejdet i det nordiske netværk "ERMOND: ecosystem resilience for mitigation of natural disasters". Netværket blev etableret i 2014 som et temaprojekt under Nordisk Ministerråd. Netværket er udpeget af "Icelandic Ministry for the Environment and Natural Resources".

Netværket har gennemgået og syntetiseret tilgængelige informationer om mulige naturkatastrofer i de nordiske lande og analyseret potentialet for at reducere effekten af naturkatastrofer gennem en målrettet forøgelse af økosystemernes resiliens. $\varnothing$ kosystemernes resiliens er også analyseret i relation til nationale politikker om restaurering af degraderede økosystemer. Følgende emner blev identificeret som løsninger for at reducere effekten af naturkatastrofer i de Nordiske lande:

- Politikker og strategier inden for området bør I højere grand end I dag erkende, at implementering af økologiske tilgange til at reducere effekten af naturkatastrofer vil blive mere og mere afgørende i lyset af befolkningstilvæksten og de prognosticerede klimaændringer.

- $\varnothing$ kologiske tilgange til at reducere effekten af naturkatastrofer bør integreres i eksisterende politikker for miljøbeskyttelse, landdistriktsudvikling og langsigtede bæredygtigheds mål.

- $\quad \varnothing$ kologisk restaurering bør kombinere mål om at reducere effekten af naturkatastrofer og forbedring af biodiversitet på en sådan måde, at der sikres en "win-win" effekt.

- $\varnothing$ kologisk restaurering af specifikke tjenester giver ofte mulige reduktioner af andre tjenester. Dette bør så vidt muligt undgås gennem integrerede mål og tilgange for restaurering.

- $\varnothing$ kologiske tilgange til at reducere effekten af naturkatastrofer bør undersøges og prioriteres med henblik på at reducere samfundenes sårbarhed overfor naturkatastrofer. 
- Politikker indenfor økologiske tilgange til at reducere effekten af naturkatastrofer bør erkende sidegevinsterne såvel for økosystemernes funktion lokalt og i en større sammenhæng, som for lokalskala økonomiske forhold og den sociale sammenhæng.

- Politikker indenfor økologiske tilgange til at reducere effekten af naturkatastrofer bør også erkende, at forebyggelse og integrerede grønne løsninger ofte vil være billigere end mindre bæredygtige tekniske løsninger eller meget dyre genopretninger efter at katastrofen er sket. Ved cost-benefit analyser af forskellige tilgange til at reducere effekten af naturkatastrofer bør alle økosystem tjenester, både direkte og indirekte, tages i betragtning.

- Langsigtede strategier for reduktion af tab og genopretning efter naturkatastrofer bør integreres i planlægning og udviklingen af bæredygtige løsninger for brug af naturen.

- Viden må genereres til opbygning af beslutningsstøttesystemer inden for økologiske tilgange til at reducere effekten af naturkatastrofer. Dette gælder erkendelse af de enkelte løsninger samt deres økologiske og økonomiske konsekvenser af deres gennemførelse.

- Økologiske tilgange til at reducere effekten af naturkatastrofer bør omfatte flere sektorer og interessenter hvis "win-win" løsninger skal udvikles. Dette gælder det politikske niveau fra lokalt til nationalt samt videnskab og teknik.

- Nordisk samarbejde indenfor økologiske tilgange til at reducere effekten af naturkatastrofer har et stort potentiale. Dette gælder også inden for EU og i bredere international sammenhæng.

Det vil have potentielt betydelige konsekvenser for de Nordiske samfund hvis vi forsat reducerer økosystemernes evne til at modvirke eller dæmpe konsekvenserne af naturkatastrofer. Resultatet af begrænset resiliens kan blive, at ellers harmløse naturkatastrofer bliver alvorlige. Dette bør adresseres.

Nordisk Ministerråd kan spille en central rolle i arbejdet for at reducere effekten af naturkatastrofer gennem økologisk restaurering. Ministerrådet kan sætte økologisk restaurering på dagsorden og det kan støtte yderligere undersøgelser og projekter direkte. Arbejdsgruppen for Terrestriske Økosystemer kan også støtte nordisk samarbejde inden for økologisk restaurering og arbejdet med at reducere effekten af naturkatastrofer. 
De nationale regeringer bør etablere og implementere mål for modvirkning af skader og økologisk baserede tilgange, hvis katastrofen har fundet sted. De bør altså formulere og implementere politikker for sådanne mål og sikre en balanceret vægtning af andre miljømål, herunder biodiversitet, landdistriktsudvikling og en bæredygtig udvikling generelt. Kommuner og andre lokale myndigheder må også implementere politiske mål og handlinger, der arbejder for økologisk restaurering og reducerer effekten af naturkatastrofer.

ERMOND netværket konkluderer, at en nordisk strategi om at reducere effekten af naturkatastrofer kan være et afgørende bidrag til at sikre nordiske samfund og reducere tab af liv og meget omkostningstunge skader. En sådan strategi kan være en international målestok og formidle internationalt samarbejde. 



\section{Appendix 1: Participants in the ERMOND network}

Active partners in the ERMOND network

Iceland

Soil Conservation Service of Iceland

- Guðmundur Halldórsson - Project Leader, Forest and restoration ecology.

- Anna María Ágústsdóttir - Project Secretary, Earth science.

- Kristín Svavarsdóttir - Senior Scientist, Restoration ecology.

Icelandic Met Office

- Sigrún Karlsdóttir - Director of Natural Hazards.

- Emmanuel Pagneux - Research Scientist, Floods.

- Gerður Stefánsdóttir - Project Manager.

Agricultural University of Iceland

- Ólafur Arnalds - Professor, Soil science.

- Ása L. Aradóttir - Professor, Restoration ecology.

National Commissioner of the Icelandic Police: Department of Civil Protection and Emergency Management

- Ágúst Gunnar Gylfason - Project Manager, Risk analysis.

Icelandic Forest Service

- Pröstur Eysteinsson - Director, Forest ecology. 


\section{Hekla Forest Project}

- Hreinn Óskarsson - Director, Forest ecology.

Reykjavík University

- David Finger - Assistant Professor.

\section{Denmark}

University of Copenhagen

- Karsten Raulund-Rasmussen - Professor, Forest ecology.

- Anders Tærø Nielsen - Post-doc, Forest ecology.

Geological Survey of Denmark and Greenland

- Hans Jörgen Henriksen.

Faroe Islands

Faroese Earth and Energy Directorate

- Lis Mortensen - Physical Geographer.

\section{Finland}

Natural Resources Institute Finland

- Anne Tolvanen-Professor, Forest ecology.

Finnish Meteorological Institute

- Karoliina Pilli-Sihvola - Research Scientist, Disaster risk reduction and climate change adaptation. 
Norway

Norwegian Institute for Nature Research

- Dagmar Hagen - Senior Research Scientist, Restoration ecology.

Norwegian Environmental Agency

- Gunnar Kjærstad - Senior Advisor.

Sweden

Umea University

- Christer Nilsson - Professor, Restoration ecology.

Partners associated to the ERMOND network

Iceland

The Environmental Agency of Iceland

- Ólafur A. Jónsson - Head of the Department for Nature.

University of Iceland

- Guðrún Pétursdóttir - Director of the Institute for Sustainability Studies.

Finland

Metsähallitus, State Forest Enterprise

- Susanna Lindeman - World Heritage coordinator. 
Sweden

Swedish Environmental Protection Agency

- Anna Lindhagen. 


\section{Appendix 2: Publications from, or in conjunction with, the ERMOND network}

\section{Reports}

Gíslason S and Bragadóttir H (editors) 2017. The Nordic Bioeconomy Initiative - Final Report, Chapter 2.2. ERMOND, pp 20-22. TemaNord 2017:526. ISBN 978-92-893-4972-7. http://dx.doi.org/10.6027/TN2017:526

Halldórsson G, Ágústsdóttir AM, Aradóttir ÁL, Arnalds Ó, Hagen D, Mortensen L, Nilsson C, Óskarsson H, Pagneux E, Pilli-Sihvola K, Raulund-Rasmussen K, Svavarsdóttir K, and Tolvanen A 2017. Ecosystem restoration for mitigation of the impacts of natural hazards: Policy Brief. ANP 2017:743. http://dx.doi.org/10.6027/ANP2017-743. Nordic Council of Ministers, Copenhagen.

Halldórsson G, Ágústsdóttir AM, Aradóttir ÁL, Arnalds Ó, Hagen D, Mortensen L, Nilsson C, Óskarsson H, Pagneux E, Pilli-Sihvola K, Raulund-Rasmussen K, Svavarsdóttir K, and Tolvanen A 2017. ERMOND: Ecosystem Restoration for Mitigation of Natural Disasters. TemaNord. In press.

Thorarinsdóttir EF, Gísladóttir FÓ, Thorsteinsdóttir AB and Halldórsson G 2017. Kortlagning á áfallapoli vistkerfa í nágrenni Heklu með tilliti til öskufalls. Skýrsla til Ofanflóðasjóðs (Mapping of the ecological resilience of ecosystems in the vicinity of Mt Hekla towards tephra fall. Report to the Icelandic Avalanche and Landslide Fund). The Soil Conservation of Iceland, 42 pp. (In Icelandic with English summary).

\section{Scientific articles}

Agustsdottir 2015. Ecosystem approach for natural hazard mitigation of volcanic tephra in Iceland: building resilience and sustainability. Natural Hazards 78 (3), 1669-1691. DOI: 10.1007/s11069-015-1795-6

Nilsson C, Sarneel JM, Palm P, Gardeström J, Pilotto F, Polvi LE, Lind L, Holmqvist D and Lundqvist $\mathrm{H}$ 2016. How do biota respond to additional physical restoration of restored streams? Ecosystems. DOI: 10.1007/s10021-016-0020-0 


\section{Manuscripts}

Agustsdottir AM et al. in manuscript. Ecological restoration and sustainable land management for disaster risk reduction of natural hazards under changing climate in the Nordic region.

Aradottir, AL and Halldorsson G. in review. Colonization of woodland species during restoration - Propagule or safe site limitation?

Nilsson C, Riis T, Sarneel JM, and Svavarsdóttir K. in review. Freshwater Floods as Natural Hazards and Ways to Cope with Them by Restoring Nature.

Ágústsdóttir et al. in prep. Effects of tephra deposition on survival and growth of young birch plantations.

Hagen et al. in prep. How to integrate ecosystem restoration with Nordic policy on restoration of degraded ecosystems.

Taeroe, Raulund-Rasmussen et al. in prep. Forest restoration for increased ecological resilience against windthrow.

\section{Abstracts}

Aradóttir ÁL. 2016. Colonization of woodland species during restoration-Safe site or propagule limitation? In: Johannes Kollmann \& Julia-Maria Hermann (eds.) SER Europe Conference 2016: Best Practice in Restoration, August 22-26, Freising, Germany, p. 96.

Ágústsdóttir AM, Bau A, Halldórsson G, Aradóttir ÁL 2016. ERMOND-Grógos: Experimental setup estimating the effect of volcanic ash deposition on restored birch woodland vegetation, Hekluskógar, Iceland. In: Johannes Kollmann \& Julia-Maria Hermann (eds.) SER Europe Conference 2016: Best Practice in Restoration, August 22-26, Freising, Germany, p. 97.

Finger D., de Lavenne A. and Jóhann Pórsson 2016. Building up Knowledge on Resilience of Fragile Lands in Subarctic Climate. EGU 2016, Vienna, Austria. http://meetingorganizer.copernicus.org/EGU2016/EGU2016-12433.pdf

Finger D., de Lavenne A., Pórsson J. 2016. Building up Knowledge on Resilience of Fragile Lands in Subarctic Climate - A Metadatabase for Land Degradation and Restoration in Southern Iceland. 3rd ES1306 Conference on Impacts of Land Management on Connectivity, February 2016, Palermo, Italy.

Finger $D$, Pétursdóttir $P$ and Halldórsson $G$ 2016. Enhancing the resilience of water resources through land restoration in Rangárvellir, Iceland - An overview of the HydroResilience project. In: Johannes Kollmann \& Julia-Maria Hermann (eds.) SER Europe Conference 2016: Best Practice in Restoration, August 22-26, Freising, Germany, p. 105.

Raulund-Rasmussen K, Taeroe A, Johannes HC. de Koning J, Larsen B. Forest restoration for increased ecological resilience against windthrows. In: Johannes Kollmann \& Julia-Maria Hermann (eds.) SER Europe Conference 2016: Best Practice in Restoration, August 22-26, Freising, Germany, p. 92. 
Nordic Council of Ministers

Ved Stranden 18

DK-1061 Copenhagen K

www.norden.org

\section{Ecosystem Restoration for Mitigation of Natural Disasters}

The Nordic network ERMOND, Ecosystem Resilience for Mitigation of Natural Disasters, reviewed information on natural hazards and ecosystem conditions in the Nordic countries. Many natural hazards put pressure on Nordic societies, primarily floods, landslides, storms, snow avalanches and volcanic activity. Intensified land use and predicted climate change are likely to increase the impacts of natural hazards in the future.

Ecosystems in good condition have the ability to reduce the impacts of natural hazards. Our study showed, however, that degradation of natural habitats in the Nordic countries may have reduced or even seriously damaged this ability. Nordic disaster risk reduction policies and strategies should recognize this situation and place restoration of degraded ecosystems on the agenda as an integrated part of future disaster risk reduction management in the Nordic countries.

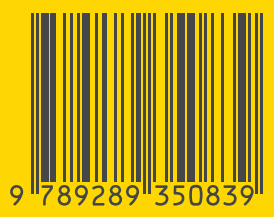

